\title{
Enrichment characteristics of radioelements in various types of rock from Sambalpur district, Orissa, India
}

\author{
A A P S R Acharyulu, B Sreenivasa Murty and B K Bhaumik \\ Physics Laboratory, Eastern Region, Atomic Minerals Directorate for Exploration and Research, Department of \\ Atomic Energy, Jamshedpur 831 002, India.
}

Over the years a large number of rock samples were collected by the explorationists of Atomic Minerals Directorate for Exploration and Research (AMD), Department of Atomic Energy from Sambalpur district, Orissa, India. The variation of uranium enrichment with various types of rock in these samples was studied with an aim to help quick reviewing of toposheets in case of newly taken up areas, for uranium exploration. The radioelements $\mathrm{U}$, Th and $\mathrm{K}$ determined for these samples are plotted in ternary diagrams for classifying them as being uraniferous or thoriferous with respect to various type of rocks, keeping the total natural content of radioelements (expressed by $\mathrm{eU}_{3} \mathrm{O}_{8}$ ) as a parameter.

In this study it is seen that samples of quartzofeldspathic breccia type are enriched in uranium irrespective of their further sub classification and $\mathrm{eU}_{3} \mathrm{O}_{8}$ content. Granites are enriched in thorium when $\mathrm{eU}_{3} \mathrm{O}_{8}<100 \mathrm{ppm}$ and are enriched in uranium when $\mathrm{eU}_{3} \mathrm{O}_{8}>100 \mathrm{ppm}$.

A database prepared for this purpose may be useful for reviewing toposheets in future.

\section{Introduction}

Uranium mineralization is controlled by many factors. It is essential to know the type of rock that is more favourable for uranium, in its exploration. Hence, an understanding of radioelemental signature in different types of rocks is required before proceeding towards further exploration of an area. These radioelemental data play a major role in undertaking further surveys and also in finding out uranium enriched zones in the area of study.

Over a period of time (1981, 1997-2000), 656 number of samples were collected from Kasipur, Jaipur, Bhatli and Bargarh sector of Sambalpur district, Orissa, India covered in toposheets no. $64 \mathrm{O} / 4,64 \mathrm{O} / 7$ and $64 \mathrm{O} / 8$, as part of the exploration program for uranium by explorationists of Atomic Minerals Directorate for Exploration and Research (AMD), Department of Atomic Energy. They are D V Katre (1981-82), A B Awati (198182), S K Das (1999-2000), P C Pant (1997-
98, 1998-99, 1999-2000), A Majumdar (199798, 1998-99), D Vidyasagar (1997-98, 1998-99, 1999-2000) and V V Sakhare (1998-99, 19992000).

These samples were analysed radiometrically first, for their $\mathrm{eU}_{3} \mathrm{O}_{8}$ content (giving the combined contribution of all the natural radioelements present) and later for the content of the individual radioelements i.e., $\mathrm{U}$, Th, and $\mathrm{K}$, in the physics laboratory of the eastern region. Since, $\mathrm{eU}_{3} \mathrm{O}_{8}$ is a measure of the sample's total natural radioactivity, it is taken as the basis even in collecting the samples in the field, in general.

Ternary diagrams are generally used to study the relationship among major oxides data of different types of rock for purposes of rock classification (Barker 1979; Tompkins 1987; Krishnamurthy 1988; Rickwood 1989). They were also used for studying the major elemental data of different types of metabasic metarhyolites and other associated rocks at Bodal, Madhya Pradesh, India (Krishnamurthy et al 1988).

Keywords. Radiometric analysis; uranium; ternary diagram; rock type; quartzofeldspathic breccia; granite. 
An effort has been made by the authors to use ternary plots for studying the distribution of radioelemental data from toposheets No. $64 \mathrm{O} / 4$, $64 \mathrm{O} / 7$ and $64 \mathrm{O} / 8$. Using these plots the authors try to present radiometric data with a view to classfying them into U-rich and U-depleted regions, keeping $\mathrm{eU}_{3} \mathrm{O}_{8}$ content of the samples as a parameter. This classification helps the explorationists who will be exploring the areas in future for locating further mineralization.

\section{Methodology of analysis and classification}

The samples collected from areas in the above mentioned toposheets were analyzed to estimate equivalent uranium concentration $\left(\mathrm{eU}_{3} \mathrm{O}_{8}\right.$, henceforth designated by eU), thorium concentration (Th), equivalent radium concentration $\left(\mathrm{Ra}\left(\mathrm{eU}_{3} \mathrm{O}_{8}\right)\right.$, henceforth designated by $\left.\mathrm{Ra}(\mathrm{eU})\right)$ and potassium concentration $(\mathrm{K})$ using four channel gamma ray spectrometer in which a $5^{\prime \prime} \times 4^{\prime \prime}$ $\mathrm{NaI}(\mathrm{Tl})$ coupled with PMT integrated crystal is used as detector. The details of the theory and instrumentation are given in Appendix 1.

Samples are initially classified into two groups based on eU values. Those containing $\mathrm{eU}<100 \mathrm{ppm}$ are named 'ppm samples'. The content of $\mathrm{Th}, \mathrm{Ra}(\mathrm{eU})$ and $\mathrm{K}$ are estimated for these ppm samples using the above technique (data given in table 1 of Appendix 2). For the other group of samples, in addition to the above, the actual concentration of uranium (designated as $\mathrm{U}(\beta-\gamma)$ ) content is measured using $\beta-\gamma$ technique (Eichholz et al 1953) (data given in table 2 of Appendix 2). This technique gives the concentration of uranium irrespective of its state of equilibrium and presence of thorium. At a level of $100 \mathrm{ppm} \mathrm{U}(\beta-\gamma)$, the precision of estimation is $11 \%$. The reason for the classification of samples into two groups is based on this precision of measurement, as we can obtain precise data for $\mathrm{U}(\beta-\gamma)$ when $\mathrm{eU} \geq 100 \mathrm{ppm}$. For ppm samples, $\mathrm{U}(\beta-\gamma)$ is not measured, as error increases.

All the concentrations i.e., eU, $\mathrm{U}(\beta-\gamma), \mathrm{Ra}(\mathrm{eU})$ and $\mathrm{Th}$ are measured in ppm and $\mathrm{K}$ in percentage. To express all the values of concentrations in ppm, $\mathrm{K}$ is converted into its ${ }^{40} \mathrm{~K}$ content and is expressed in ppm. (Natural abundance of ${ }^{40} \mathrm{~K}$ is $0.0118 \%$. This implies that $1 \% \mathrm{~K}$ contains $1.18 \mathrm{ppm}$ of ${ }^{40} \mathrm{~K}$. Likewise, $2 \% \mathrm{~K}$ contains $2.36 \mathrm{ppm}$ of $\left.{ }^{40} \mathrm{~K}\right]$.

Whenever, $\mathrm{U}$ or $\mathrm{Th}$ concentration of sample becomes very high, determination of ${ }^{40} \mathrm{~K}$ is very difficult due to Compton scattering giving poor precision of measurement. Hence, its measurement is not done for these samples. In those cases, potassium values either from chemical method of assay or the natural abundance of ${ }^{40} \mathrm{~K}$ for that type of rock have to be taken.

The data i.e., $\mathrm{U}(\beta-\gamma)$, Th and ${ }^{40} \mathrm{~K}$ in case of samples with eU $>100 \mathrm{ppm}$ and $\mathrm{Ra}(\mathrm{eU})$, Th and ${ }^{40} \mathrm{~K}$ in case of samples with $\mathrm{eU}<100 \mathrm{ppm}$ are plotted using ternary diagrams. For samples with $\mathrm{eU}>100 \mathrm{ppm}, \mathrm{U} / \mathrm{K}, \mathrm{Th} / \mathrm{K}$ and $\mathrm{U} / \mathrm{Th}$ ratios were also plotted on ternary diagrams to study their behaviour. Ratios are used for finding preferential enrichment of uranium with respect to thorium and potassium.

\section{Interpretation}

\subsection{Granites and basics}

In this category, we have samples belonging to granites, quartzofeldspathic breccia/granite (QFB/granite), granitic gneisses, brecciated granite, sheared granites, granitic cataclasites, sheared basics, sheared metabasics and basic rock. The breakup of the number of samples is given in table 1 . The radioelemental data for these samples are recalculated to $100 \%$ and plotted on triangular diagram (figure 1). In this figure, samples from granite type of rock with eU $<100 \mathrm{ppm}$ are denoted

Table 1. Categorization of samples based on eU values.

Rock type eU $>100 \mathrm{ppm} \quad \mathrm{eU}<100 \mathrm{ppm}$

Granite and basic rock related:

Granite

10

QFB/granite

82

Brecciated granite

Sheared granite

Granitic gneisses

4

9

Granitic cataclasite

$-$

6

Sheared metabasic

Basic

3

QFB related:

QFB

QFB/Br. Granite

QFB/Breccia

159

2

Mylonite related:

Mylonite

$$
10
$$

15

Mylonite/QFB

\section{1}

Sandstone

1

Sandstone/shale

$-$

Sheared sandstone

Conglomerate

$-$

Pebbly sandstone

58

1

$-$

13

2

2

-

74

9

34

${ }^{*}=$ Samples are less in number; $-=$ No samples in this category. 


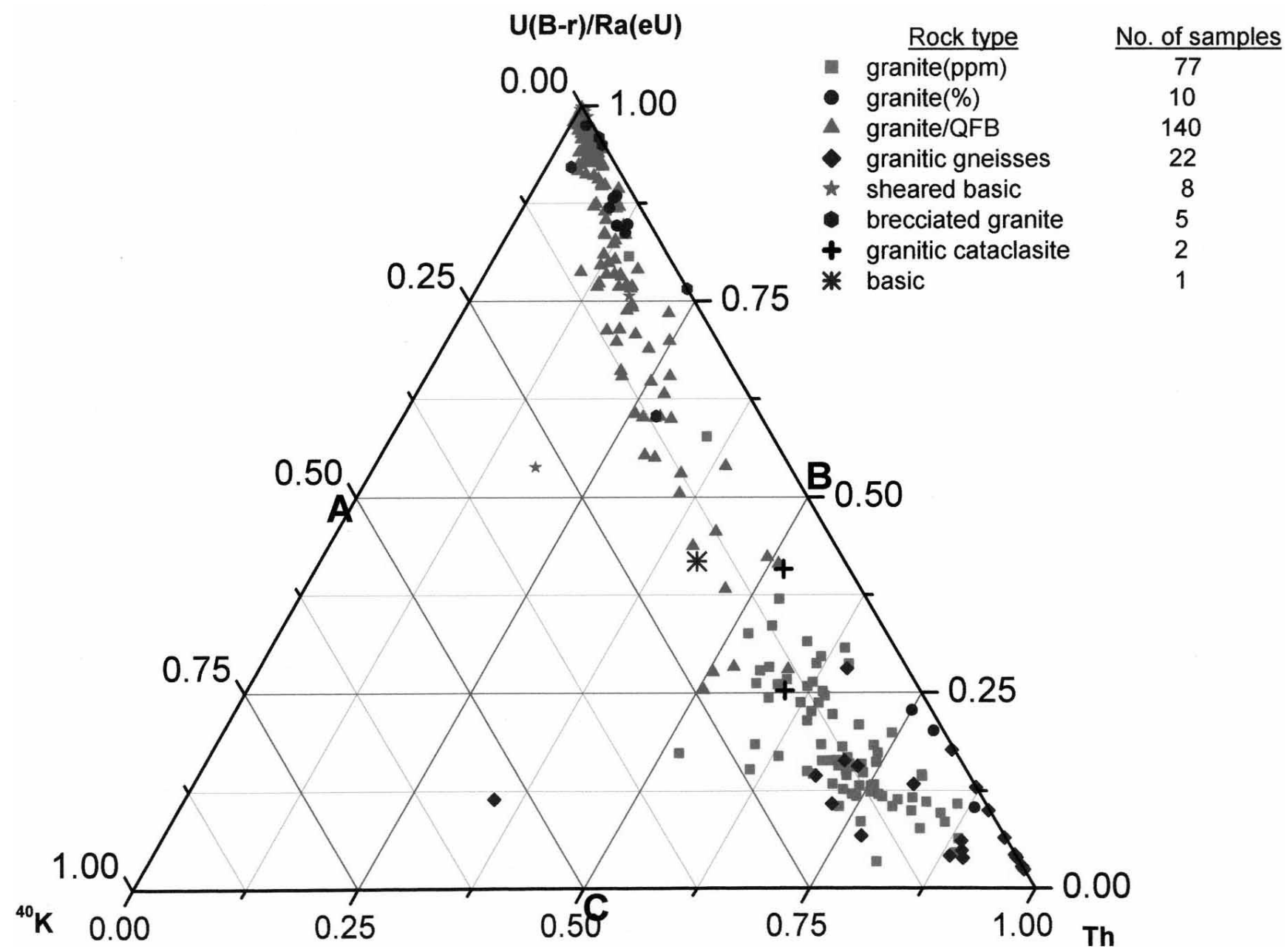

Figure 1. Ternary diagram for granite and basic rock related data.

by granite (ppm) and the same with eU $>100 \mathrm{ppm}$, by granite(\%). Samples from other types of rock are not separated based on eU value.

From this figure, we can observe that all granite samples with eU $<100 \mathrm{ppm}$ show a trend towards high Th (more than 50\% line $\mathrm{BC}$ to apex $\mathrm{Th}$ ), whereas, samples with eU $>100 \mathrm{ppm}$ show uranium enrichment ( $75 \%$ contribution above the line AB). Three samples are exceptions, where Th is more.

QFB/granite samples show a trend towards high $\mathrm{Ra}(\mathrm{eU}) /$ uranium enrichment irrespective of their $\mathrm{eU}$ content (more than $50 \%$ line $\mathrm{AB}$ to apex U(B$\mathrm{r}) / \mathrm{Ra}(\mathrm{eU}))$. Brecciated granites and sheared basics also show a trend towards uranium/Ra(eU). In sheared granites and sheared metabasics, we have samples in eU >100 ppm category. They also show uranium enrichment ( $75 \%$ contribution above the line $\mathrm{AB}$ ).

All the granitic gneisses are enriched in thorium whereas granitic cataclasite samples show thorium variation between $50 \%$ and $60 \%$ and equivalent radium variation between $25 \%$ and $50 \%$. Average $\mathrm{U}$, Th and $\mathrm{Ra}(\mathrm{eU})$ values are tabulated in table 2. Brecciated granites are highly enriched in uranium i.e., a median value of $0.88 \%$ whereas granitic gneisses are highly enriched in thorium i.e., a median value of $0.15 \%$.

From the figure 1, we can observe that granites with $\mathrm{eU}<100 \mathrm{ppm}$ show $\mathrm{Th}$ enrichment whereas granites with eU $>100 \mathrm{ppm}$ reveal enrichment of uranium or $\mathrm{Ra}(\mathrm{eU})$. Granitic gneisses show thorium enrichment irrespective of their eU value.

\subsection{Quartzofeldspathic Breccia (QFB)}

In this type, we have QFB, QFB/breccia and $\mathrm{QFB} /$ brecciated granites. The sample breakup is given in table 1 . The corresponding radiometric data are plotted in figure 2. Here also, samples from QFB type of rock with $\mathrm{eU}<100 \mathrm{ppm}$ are denoted by $\mathrm{QFB}(\mathrm{ppm})$ and samples with eU $>100 \mathrm{ppm}$ are denoted by QFB(\%). Same notation is followed for other types of rock also.

Here the trend is mixed. Out of 117 samples with $\mathrm{eU}<100 \mathrm{ppm}$, the maximum number of samples (106) contain $\mathrm{Ra}(\mathrm{eU})$ more than $50 \%$ (above 
Table 2. Average and median values for granite and basic rock related data.

(a) eU $<100$ ppm

\begin{tabular}{lcc}
\hline Rock type & Th(Av.)(ppm) & $\operatorname{Ra}(\mathrm{eU})(\mathrm{Av}).(\mathrm{ppm})$ \\
\hline Granite & 28 & 9 \\
QFB/granite & 11 & 42 \\
Granitic cataclasite & 38 & 24 \\
Granitic gneisses & 61 & 6 \\
Sheared basic & 5 & 18 \\
\hline
\end{tabular}

(b) eU > $100 \mathrm{ppm}$

\begin{tabular}{lcc}
\hline Rock type & Th(Median $)(\mathrm{ppm})^{*}$ & $\mathrm{U}($ Median $)(\mathrm{ppm})^{*}$ \\
\hline Granite & $14(10-430)$ & $100(40-600)$ \\
QFB/granite & $11(1-49)$ & $330(100-880)$ \\
Brecciated granite & $420(40-10000)$ & $8800(130-33000)$ \\
Sheared granite & $6(1-19)$ & $580(140-1500)$ \\
Granitic gneisses & $1500(370-6000)$ & $80(40-550)$ \\
Sheared basic & $9(1-22)$ & $1700(860-3100)$ \\
Sheared metabasic & 2 & 2300
\end{tabular}

$*$ Range given in parenthesis.

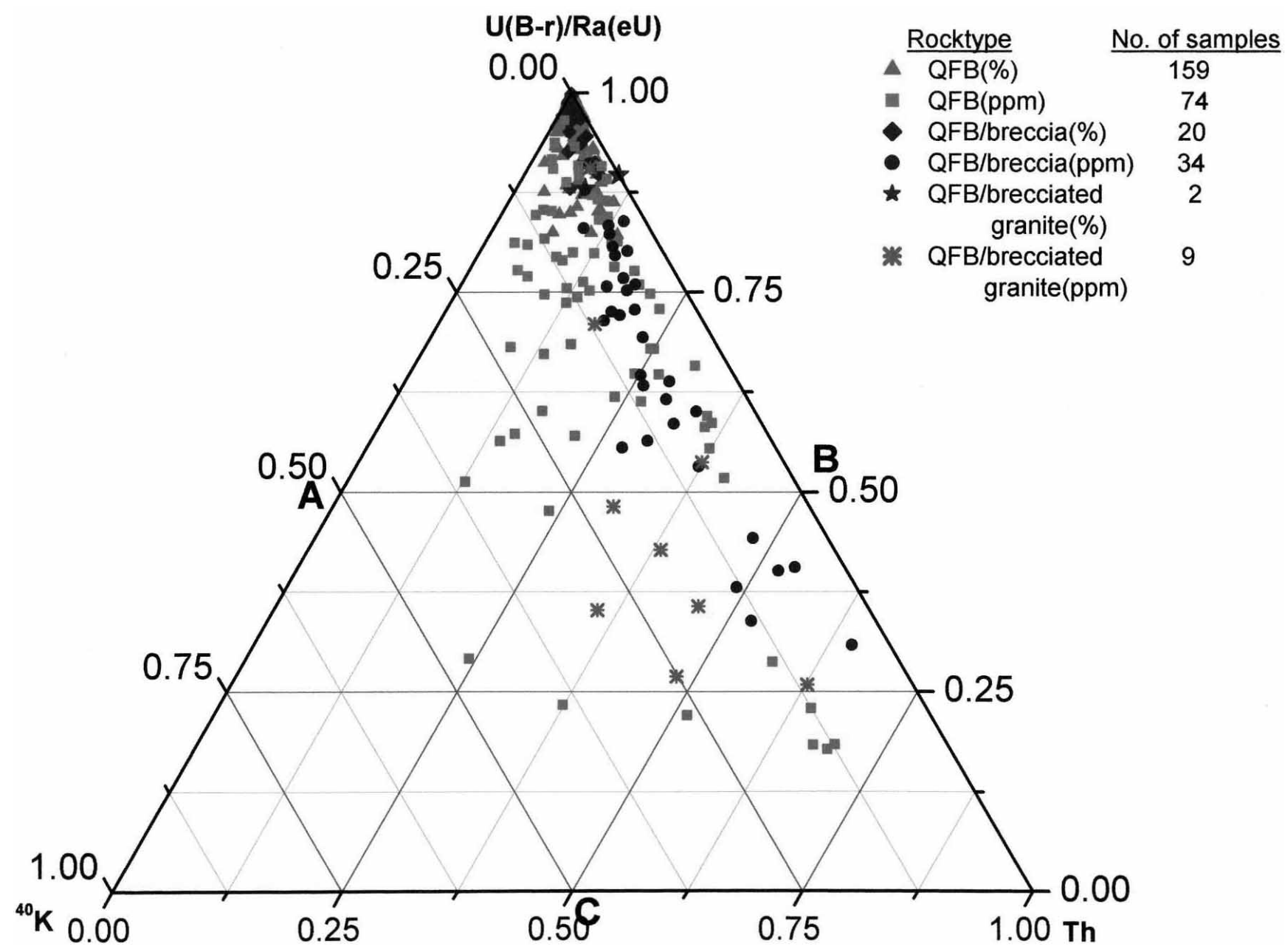

Figure 2. Ternary diagram for QFB related data. 
Table 3. Average and median values for QFB related data.

(a) $\mathrm{eU}<100 \mathrm{ppm}$

\begin{tabular}{lcc}
\hline Rock type & $\operatorname{Th}($ Av. $)(\mathrm{ppm})$ & $\operatorname{Ra}(\mathrm{Av}).(\mathrm{ppm})$ \\
\hline QFB & 9 & 44 \\
QFB/brecciated granite & 18 & 29 \\
QFB/breccia & 11 & 35 \\
\hline
\end{tabular}

(b) $\mathrm{eU}>100 \mathrm{ppm}$

\begin{tabular}{lcc}
\hline Rock type & Th(Median $)(\mathrm{ppm})^{*}$ & $\mathrm{U}($ Median $)(\mathrm{ppm})^{*}$ \\
\hline QFB & $5(1-220)$ & $230(70-7700)$ \\
QFB/brecciated granite & 978 & 8530 \\
QFB/breccia & $4(1-29)$ & $295(10-1300)$
\end{tabular}

${ }^{*}=$ Range given in parenthesis.

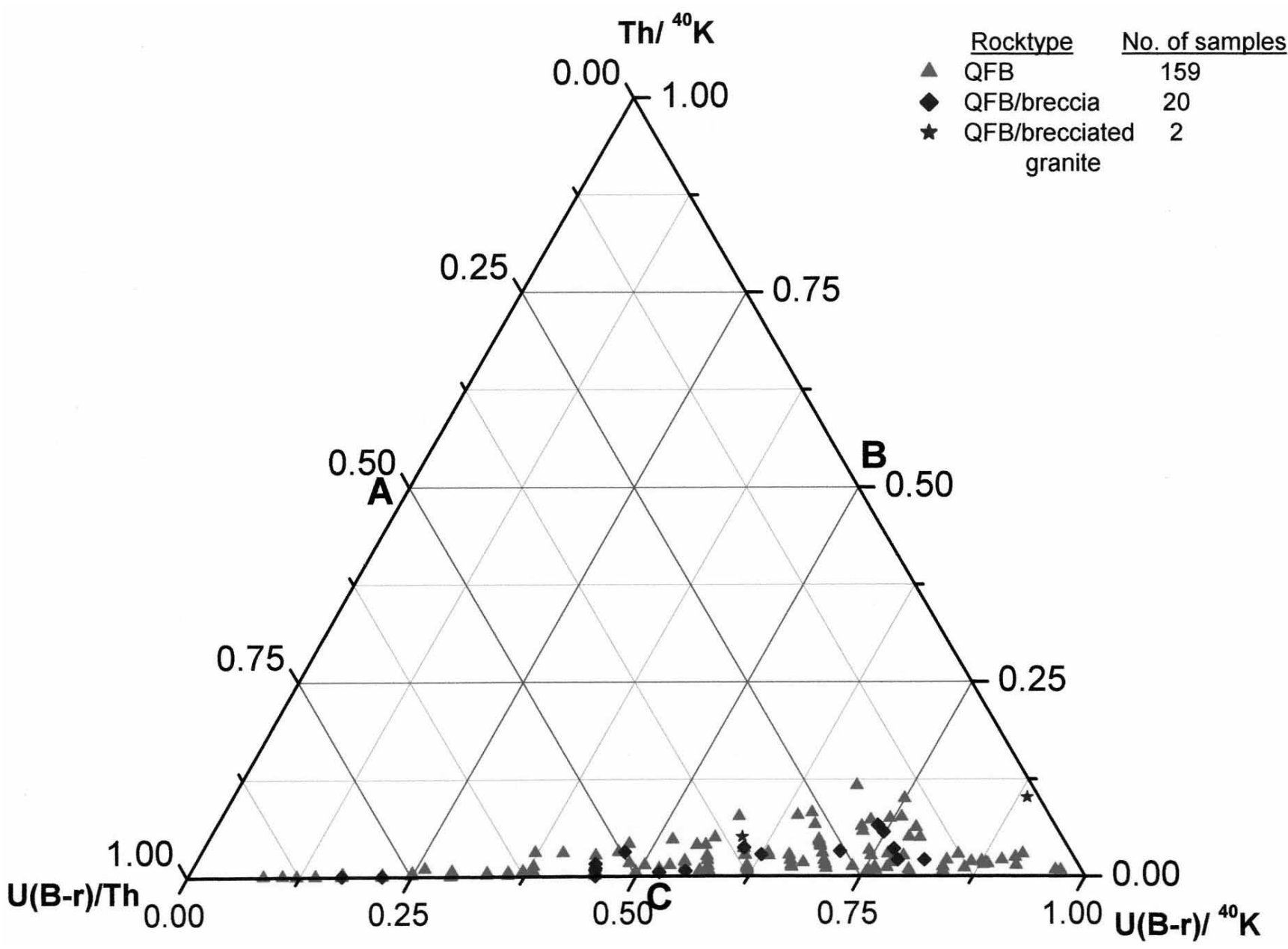

Figure 3. Ternary diagram for ratios of $\mathrm{QFB}$ data (eU > $100 \mathrm{ppm})$.

line $\mathrm{AB}) .11$ samples contain $\mathrm{Ra}(\mathrm{eU})$ between $25 \%$ and $50 \%$. Samples with eU >100 ppm (181 in number) show enrichment of uranium irrespective of their rock type. Median values are given in table 3 . A median value of $295 \mathrm{ppm}$ uranium is found for $\mathrm{QFB} /$ breccia.
An interesting aspect with this kind of radioelement data presentation lies in the fact that apex ${ }^{40} \mathrm{~K}$ acts like a peg with which a cluster of sample is tied and the movement of the cluster at the other apices is controlled by $\mathrm{U}$ or Th enrichment. 


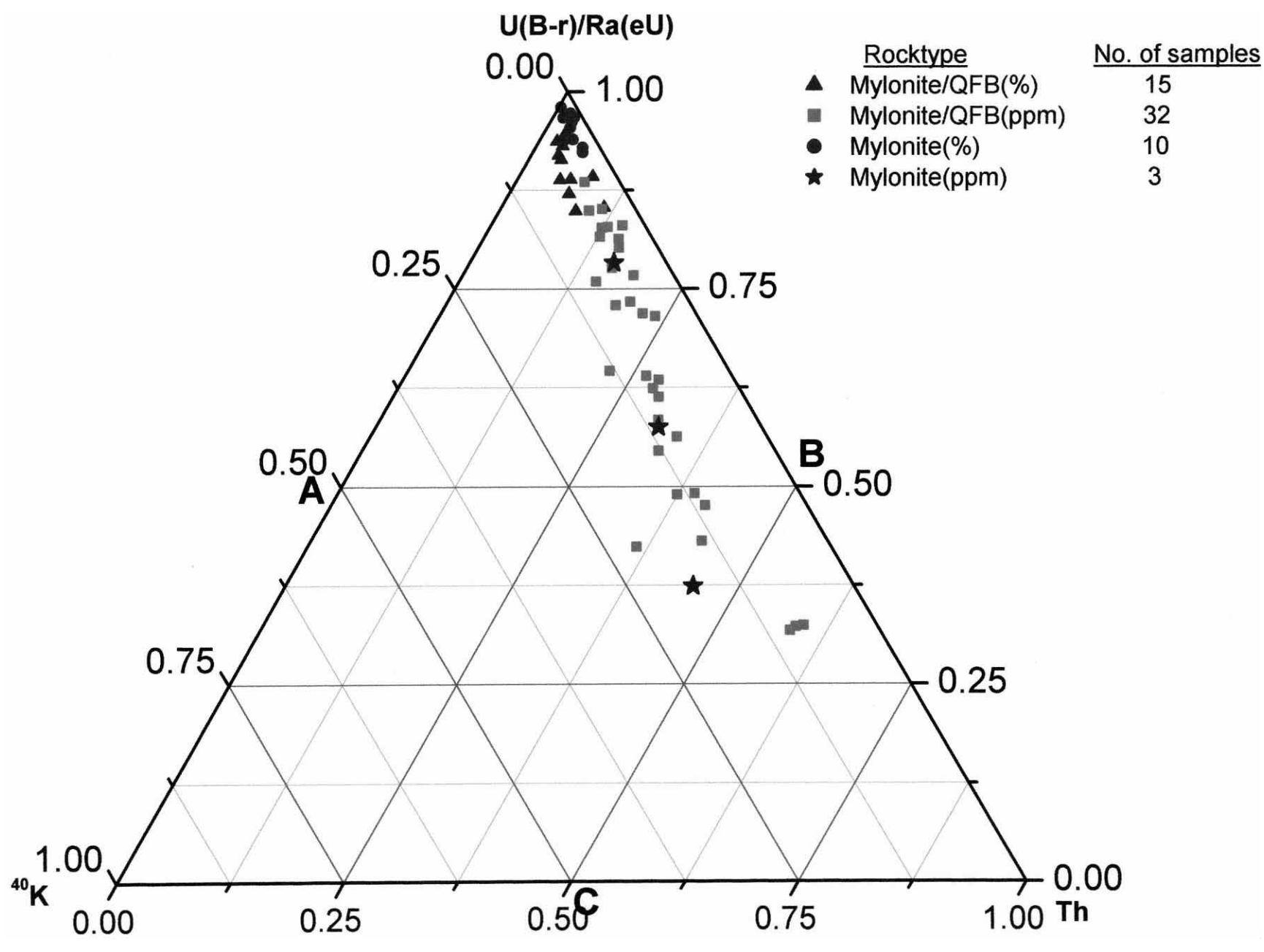

Figure 4. Ternary diagram for mylonite related data.

The ratios $\mathrm{U} /{ }^{40} \mathrm{~K}, \mathrm{Th} /{ }^{40} \mathrm{~K}$ and $\mathrm{U} / \mathrm{Th}$ for samples with eU $>100$ ppm are plotted in figure 3 on a ternary diagram. These samples show preferential enrichment of $\mathrm{U}$ with respect to ${ }^{40} \mathrm{~K}$. From the published data (table 5), it can be observed that all the types of rock (igneous, sedimentary and metamorphic) have $\mathrm{Th} / \mathrm{K}$ ratio lying between $50 \%$ and $83 \%$, showing that enrichment of thorium with respect to $\mathrm{K}$ is more. When the points fall below the line $\mathrm{AB}$ of figure 3, then uranium enrichment with $\mathrm{K}$ or Th is more. The point $\mathrm{C}$ in figure 3 , where the sample is enriched in uranium equally with respect to both thorium and potassium, would be preferred.

From the figures 2 and 3, it can be seen that all the samples (from QFB) irrespective of their subclassification and content of eU, show enrichment of either $\mathrm{Ra}(\mathrm{eU})$ or uranium.

\subsection{Mylonites}

In this category, we have mylonite and mylonite/QFB. The number of samples is given in table 1 . The radiometric data are plotted on ternary diagram (figure 4). Here also, samples with $\mathrm{eU}<100 \mathrm{ppm}$ are denoted by 'ppm' in parenthesis and samples with eU >100 ppm denoted by '\%' in parenthesis.

Samples with eU $<100$ ppm (35 samples) are distributed evenly. But, it can be observed that the variation of $\mathrm{Ra}(\mathrm{eU})$ lies between $50 \%$ and $100 \%$, Th is between 0 and $50 \%$ and ${ }^{40} \mathrm{~K}$ variation is within $25 \%$. From this, we can say that there is a trend towards enrichment of $\mathrm{Ra}(\mathrm{eU})$ in maximum number of samples. Whereas, samples with eU > 100 ppm (25 samples) show very high uranium and very less $\mathrm{Th}$ and ${ }^{40} \mathrm{~K}$. All the samples show $\mathrm{U}(\beta-\gamma)$ more than $85 \%$. Median values are shown in table 4 . The mylonite type of rocks have reported a value of $280 \mathrm{ppm}$ uranium (median value).

From figure 4, it can be seen that mylonites irrespective of their eU concentration show either $\mathrm{Ra}(\mathrm{eU})$ or uranium and less Th.

\subsection{Sandstone}

In this type of rock, we have sandstone, shale, sandstone/shale, sheared sandstone, conglomer- 
Table 4. Average and median values for mylonite related data.

(a) $\mathrm{eU}<100 \mathrm{ppm}$

\begin{tabular}{lcc}
\hline Rock type & $\operatorname{Th}($ Av. $)(\mathrm{ppm})$ & $\mathrm{Ra}(\mathrm{Av}).(\mathrm{ppm})$ \\
\hline Mylonite & 11 & 31 \\
Mylonite/QFB & 12 & 37
\end{tabular}

(b) eU $>100 \mathrm{ppm}$

\begin{tabular}{lcc}
\hline Rock type & $\mathrm{Th}($ Median$)(\mathrm{ppm})^{*}$ & $\mathrm{U}($ Median $)(\mathrm{ppm})^{*}$ \\
\hline Mylonite & $7(1-13)$ & $280(150-400)$ \\
Mylonite/QFB & $7(5-16)$ & $150(90-300)$ \\
\hline
\end{tabular}

${ }^{*}=$ Range given in parenthesis.

Table 5. Estimated ratios from published data (Galbraith $J$ H, et al (1983)).

\begin{tabular}{lccc}
\hline Rock type & $\mathrm{U} / \mathrm{K}$ & $\mathrm{Th} / \mathrm{K}$ & $\mathrm{U} / \mathrm{Th}$ \\
\hline Igneous & & & \\
Ultrabasic & $0.71(23 \%)$ & $2.0(65 \%)$ & $0.36(12 \%)$ \\
Basic & $0.77(18 \%)$ & $3.4(77 \%)$ & $0.23(5 \%)$ \\
Basic-Intermediate & $0.91(21 \%)$ & $3.2(73 \%)$ & $0.28(6 \%)$ \\
Intermediate & $1.25(22 \%)$ & $4.1(73 \%)$ & $0.30(5 \%)$ \\
Intermediate-Acidic & $1.25(18 \%)$ & $5.3(78 \%)$ & $0.23(3 \%)$ \\
Acidic & $1.11(15 \%)$ & $6.3(83 \%)$ & $0.19(2 \%)$ \\
Sedimentary & & & \\
Evaporite & $1.0(19 \%)$ & $4.0(76 \%)$ & $0.25(5 \%)$ \\
Carbonate & $5.0(42 \%)$ & $5.9(50 \%)$ & $1.0(8 \%)$ \\
Sandstone & $1.7(25 \%)$ & $4.8(71 \%)$ & $0.33(5 \%)$ \\
Shale & $1.4(24 \%)$ & $4.1(70 \%)$ & $0.32(6 \%)$ \\
Metamorphic & & & \\
Amphibolite & $1.43(28 \%)$ & $3.3(64 \%)$ & $0.45(9 \%)$ \\
Greenstone & $0.77(18 \%)$ & $3.4(77 \%)$ & $0.23(5 \%)$ \\
Graywacke & $0.77(22 \%)$ & $2.4(69 \%)$ & $0.31(9 \%)$ \\
Gneiss & $0.67(17 \%)$ & $3.1(78 \%)$ & $0.22(6 \%)$ \\
Schist & $1.7(22 \%)$ & $5.5(74 \%)$ & $0.30(4 \%)$ \\
Percentage val & & &
\end{tabular}

Percentage values given in parenthesis.

ate and pebbly sandstone (table 1 ). In these, 24 samples have $\mathrm{eU}<100 \mathrm{ppm}$ and 2 samples have eU $>100$ ppm. Samples with eU $<100$ ppm show a trend towards Th enrichment with an exception of four samples (figure 5). Four samples show enrichment of $\mathrm{Ra}(\mathrm{eU})$.

Out of 2 samples with eU $>100 \mathrm{ppm}$, one is sandstone type and is thoriferous and the other is shale and is uraniferous. Due to lack of a sufficient number of samples, it would not be appropriate to draw a conclusion.

\section{Conclusion}

From the discussion above, it is observed that in the category of granitic and basic related samples, granites are enriched in thorium when $\mathrm{eU}<100 \mathrm{ppm}$ and are enriched in uranium when eU > 100 ppm; whereas, granitic gneisses are enriched in thorium irrespective of their eU content. Samples in QFB category, irrespective of their subclassification and eU content, are enriched in uranium. The same is true with mylonite type of samples. Sandstone type of samples show enrichment of thorium, even though, the number of samples is not sufficient. These conclusions are tabulated in table 6 . Location of the samples which show uranium (or) radium enrichment is shown in figure 6 . In the marked areas, uranium (or) radium is preferentially enriched with respect to both ${ }^{40} \mathrm{~K}$ and Th. Most of these enriched samples are associated with quartzofeldspathic breccia. 


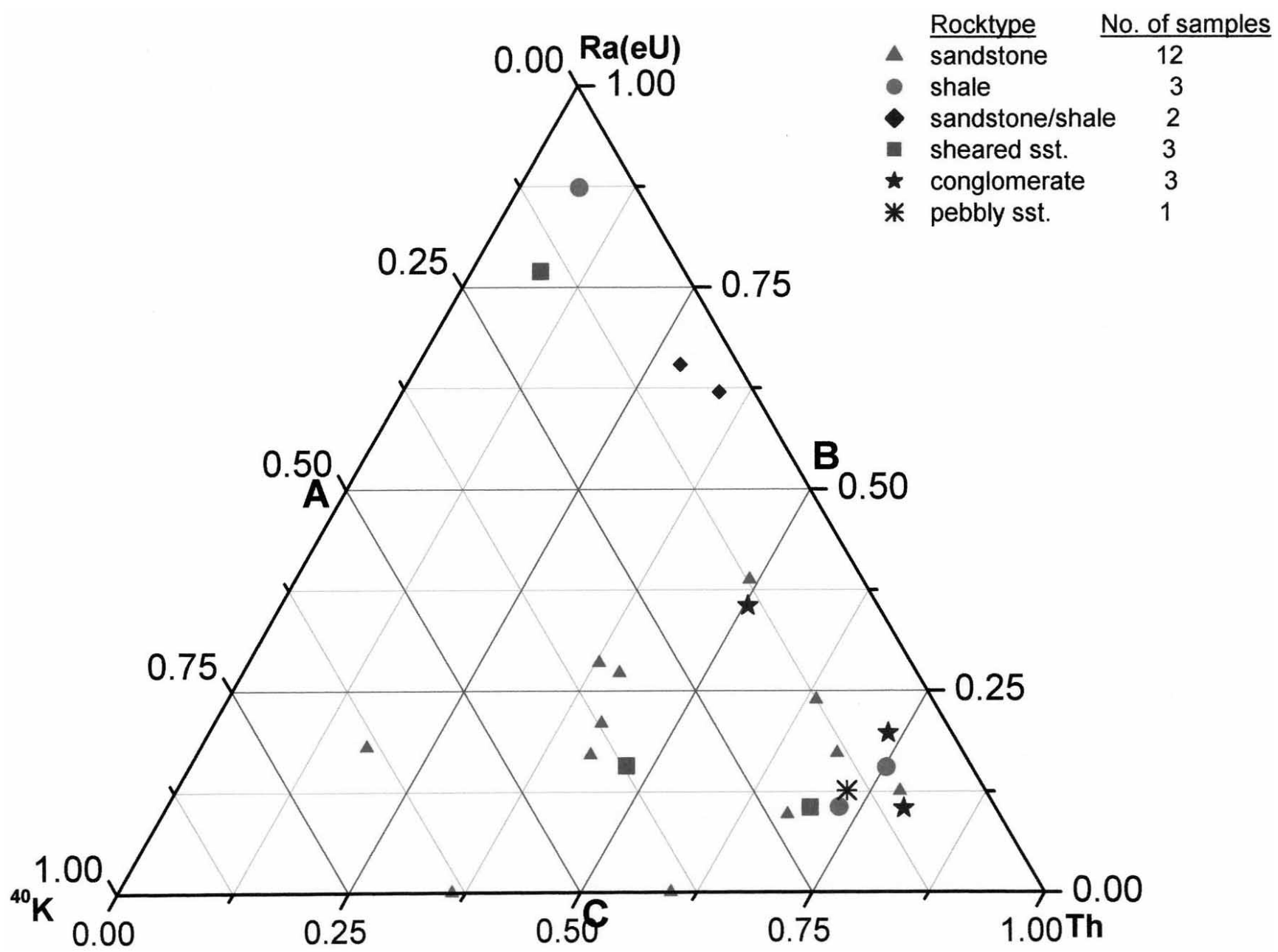

Figure 5. Ternary diagram for sandstone related data (eU $<100 \mathrm{ppm}$ ).

This work may help in the future exploration in the area of study, to find out more uraniferous zones. Since the aim of our exploration is to find large uranium resources this study reveals that we should look for more QFB type, mylonitic samples or granitic samples with eU $>100 \mathrm{ppm}$ so that we can find out more uranium enriched areas.

We have prepared a "radiometric database" where all the available radiometric data with physics laboratory, eastern region have been incorporated into the database. We propose to provide the data (table 7) to all the explorationists who take decisions to review the same toposheets and its adjoining areas in future.

\section{Acknowledgements}

We gratefully acknowledge the helpful suggestions provided by our colleagues in the physics laboratory, eastern region, particularly Sri T. Bhattacharya for radiometric analysis of samples.

\section{Appendix 1}

The experimental setup consists of a $5^{\prime \prime} \times 4^{\prime \prime} \mathrm{NaI}$ (Tl) crystal detector coupled to a $5^{\prime \prime}$ dia photomultiplier tube (PMT) and the electronic circuitry consisting of pre-amplifier, high voltage unit, spectroscopy amplifier, four single channel analysers, four counter timers and two nuclear instrumentation bins. The detector assembly is enclosed in a lead chamber of $4^{\prime \prime}$ thick (figure 7).

For estimation of $\mathrm{K}, \mathrm{Ra}(\mathrm{eU})$ and $\mathrm{Th}$ the corresponding energies i.e., $1.46 \mathrm{Mev}, 1.76 \mathrm{Mev}$ and $2.62 \mathrm{Mev}$ are used. For estimation of eU a channel for total counting is used. Accordingly the windows are fixed (Grasty 1979).

For $\mathrm{K}$, the window is $1.36 \mathrm{Mev}-1.56 \mathrm{Mev}$.

For $\mathrm{Ra}(\mathrm{eU})$, the window is $1.66 \mathrm{Mev}-1.86 \mathrm{Mev}$.

For Th, the window is $2.42 \mathrm{Mev}-2.82 \mathrm{Mev}$ and for total channel the window is $0.40 \mathrm{Mev}-$ $3.0 \mathrm{Mev}$.

The rate of count in total channel provides an idea about eU content of the sample. It is the com- 
Table 6. Summary of trends.

\begin{tabular}{|c|c|c|}
\hline Rock type & $\mathrm{eU}>100 \mathrm{ppm}$ & $\mathrm{eU}<100 \mathrm{ppm}$ \\
\hline \multicolumn{3}{|c|}{ Granite and basic rock related: } \\
\hline Granite & Uranium enrichment & Thorium enrichment \\
\hline QFB/granite & Uranium enrichment & $\mathrm{Ra}(\mathrm{eU})$ enrichment \\
\hline Brecciated granite & Uranium enrichment & $\mathrm{Ra}(\mathrm{eU})$ enrichment \\
\hline Sheared granite & Uranium enrichment & - \\
\hline Sheared basic & Uranium enrichment & $\mathrm{Ra}(\mathrm{eU})$ enrichment \\
\hline Sheared metabasic & Uranium enrichment & - \\
\hline Granitic gneisses & Thorium enrichment & Thorium enrichment \\
\hline Granitic cataclasite & - & Thorium enrichment \\
\hline Basic & - & Both Th, Ra enrichment \\
\hline \multicolumn{3}{|l|}{ QFB related: } \\
\hline QFB & Uranium enrichment & $\mathrm{Ra}(\mathrm{eU})$ enrichment \\
\hline QFB/Br. Granite & Uranium enrichment & $\mathrm{Ra}(\mathrm{eU})$ enrichment \\
\hline QFB/Breccia & Uranium enrichment & $\mathrm{Ra}(\mathrm{eU})$ enrichment \\
\hline \multicolumn{3}{|l|}{ Mylonite related: } \\
\hline Mylonite & Uranium enrichment & $\mathrm{Ra}(\mathrm{eU})$ enrichment \\
\hline Mylonite/QFB & Uranium enrichment & $\mathrm{Ra}(\mathrm{eU})$ enrichment \\
\hline \multicolumn{3}{|c|}{ Sandstone related ${ }^{*}$ : } \\
\hline Sandstone & - & Thorium enrichment \\
\hline Shale & - & Thorium enrichment \\
\hline Sandstone/shale & - & $\mathrm{Ra}(\mathrm{eU})$ enrichment \\
\hline Sheared sandstone & - & Thorium enrichment \\
\hline Conglomerate & - & Thorium enrichment \\
\hline Pebbly sandstone & - & Thorium enrichment \\
\hline
\end{tabular}

${ }^{*}=$ Samples are less in number; $-=$ No samples in this category.

bined contribution of all the radioelements present in the sample. It is given by:

$$
\% \mathrm{eU}=\left(N_{S} / N_{U}\right) *\left(M_{U} / M_{S}\right) * U_{\mathrm{std}}
$$

where, $N_{S}$ is net rate of count in total channel due to a sample of mass $M_{S}$,

$N_{U}$ is net rate of count in total channel due to $\mathrm{U}_{3} \mathrm{O}_{8}$ standard of mass $M_{U}$ and concentration $U_{\text {std }}$.

Even though the sample contains all natural radioelements, since it is compared to a known $\mathrm{U}_{3} \mathrm{O}_{8}$ standard, this measurement is denoted as equivalent uranium measurement i.e., eU.

To account for contributions of Th and $\mathrm{Ra}(\mathrm{eU})$ in other channels four constants known as stripping constants are defined as given below:

$\alpha=$ counts in $\mathrm{Ra}(\mathrm{eU})$ channel due to one count

in Th channel from thorium standard,

$\beta=$ counts in $\mathrm{K}$ channel due to one count in Th channel from thorium standard,

$\gamma=$ counts in $\mathrm{K}$ channel due to one count in $\mathrm{Ra}(\mathrm{eU})$ channel from uranium standard, $\mathrm{a}=$ counts in Th channel due to one count in $\mathrm{Ra}(\mathrm{eU})$ channel from uranium standard.

Now, let $K_{g}, R a_{g}, T h_{g}$ be the observed counts after subtracting background in $\mathrm{K}, \mathrm{Ra}(\mathrm{eU})$ and $\mathrm{Th}$ channels respectively. These counts will have contributions from $\mathrm{K}, \mathrm{Ra}(\mathrm{eU})$ and $\mathrm{Th}$ respectively as well as the contributions from inter channels. To find out the net counts due to the respective elements, the contributions from other channels need to be subtracted from these counts. This results in the following equations:

$$
\begin{aligned}
\mathrm{Th}_{\mathrm{n}}= & \mathrm{Th}_{\mathrm{g}}-\mathrm{Ra}_{\mathrm{n}} \\
& \left(\mathrm{Th}_{\mathrm{n}}: \text { net counts in thorium channel }\right) \\
\mathrm{Ra}_{\mathrm{n}}= & \mathrm{Ra}_{\mathrm{g}}-\alpha \mathrm{Th}_{\mathrm{n}} \\
& \left(\mathrm{Ra}_{\mathrm{n}}: \text { net counts in radium channel }\right) \\
\mathrm{K}_{\mathrm{n}}= & \mathrm{K}_{\mathrm{g}}-\beta \mathrm{Th} \mathrm{h}_{\mathrm{n}}-\gamma \mathrm{Ra}_{\mathrm{n}} \\
& \left(\mathrm{K}_{\mathrm{n}} \text { : net counts in potassium channel }\right) .
\end{aligned}
$$

Solving these equations, gives the formulae for $\mathrm{Ra}(\mathrm{eU})$, Th and $\mathrm{K}$ concentrations.

They are,

$$
\mathrm{Ra}(\mathrm{eU})=\left(\mathrm{Ra}_{\mathrm{g}}-\alpha \mathrm{Th}_{\mathrm{g}}\right) /(1-\mathrm{a} \alpha) \mathrm{S}_{\mathrm{Ra}}
$$




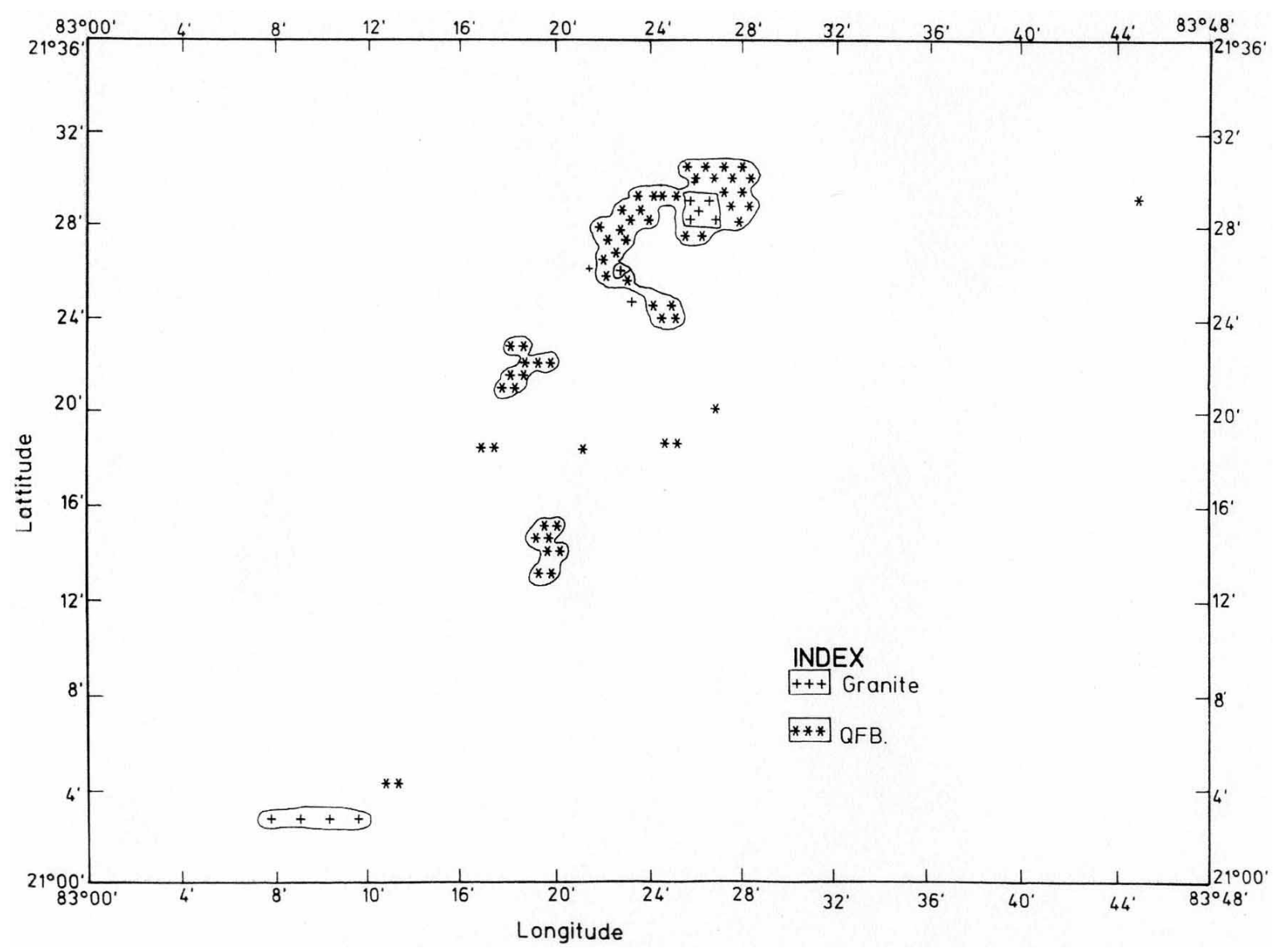

Figure 6. Location for samples showing uranium enrichment.

Table 7. Example of output from "Radiometric database".

\begin{tabular}{|c|c|c|c|c|c|c|c|c|c|c|c|c|}
\hline & Latitud & & & ongitud & & & & $\mathrm{eU}_{3} \mathrm{O}_{8}$ & $\mathrm{U}_{3} \mathrm{O}_{8}$ & $\mathrm{ThO}_{2}$ & $\mathrm{Ra}(\mathrm{eU})$ & K \\
\hline Degs & Mins & Secs & Degs & Mins & Secs & Rock type & Location & ppm & ppm & ppm & ppm & $\%$ \\
\hline 21 & 27 & 40 & 83 & 22 & 15 & Sandstone & Kashipali & 120 & 50 & 224 & 14 & 2 \\
\hline 21 & 16 & 15 & 83 & 16 & 15 & & Kermali & 29 & - & 24 & 9 & 4 \\
\hline 21 & 12 & 30 & 83 & 16 & 30 & & Sargorapali & 8 & - & 2 & 0 & 3 \\
\hline 21 & 10 & 0 & 83 & 15 & 15 & & Kuchipali & 10 & - & 4 & 2 & 3 \\
\hline 21 & 8 & 0 & 83 & 14 & 0 & & Jampali & 12 & - & 7 & 0 & 4 \\
\hline 21 & 17 & 15 & 83 & 16 & 0 & & Chibra & 12 & - & 4 & 3 & 3 \\
\hline 21 & 6 & 15 & 83 & 13 & 30 & $\downarrow$ & Kurlubahal & 41 & - & 50 & 8 & 5 \\
\hline 21 & 5 & 15 & 83 & 13 & 45 & & Diptipur & 14 & - & 5 & 2 & 4 \\
\hline 21 & 5 & 0 & 83 & 13 & 0 & Sandstone & Tal & 9 & - & 7 & 1 & 2 \\
\hline
\end{tabular}

$-=$ Poor precision.

$$
\begin{aligned}
\mathrm{Th}= & \left(\mathrm{Th}_{\mathrm{g}}-\mathrm{aRa} \mathrm{a}_{\mathrm{g}}\right) /(1-\mathrm{a} \alpha) \mathrm{S}_{\mathrm{Th}} \\
\mathrm{K}= & {\left[\mathrm{K}_{\mathrm{g}}-((\gamma-\beta \mathrm{a}) /(1-\mathrm{a} \alpha)) \mathrm{Ra}_{\mathrm{g}}\right.} \\
& \left.-((\beta-\gamma \alpha) /(1-\mathrm{a} \alpha)) \mathrm{Th}_{\mathrm{g}}\right] / \mathrm{S}_{\mathrm{K}}
\end{aligned}
$$

where, $S_{K}=$ Sensitivity of potassium channel (counts/\%/sec)

$$
\begin{aligned}
\mathrm{S}_{\mathrm{Ra}}= & \text { Sensitivity of radium channel } \\
& (\text { counts } / \mathrm{ppm} / \mathrm{sec}) \\
\mathrm{S}_{\mathrm{Th}}= & \text { Sensitivity of thorium channel } \\
& (\text { counts } / \mathrm{ppm} / \mathrm{sec}) .
\end{aligned}
$$

In the laboratory, the windows are setup using ${ }^{137} \mathrm{Cs}$ and ${ }^{60} \mathrm{Co}$ standards. Known equilibrium $\mathrm{U}_{3} \mathrm{O}_{8}, \mathrm{ThO}_{2}$ and $\mathrm{K}$ standards are used for calculat- 


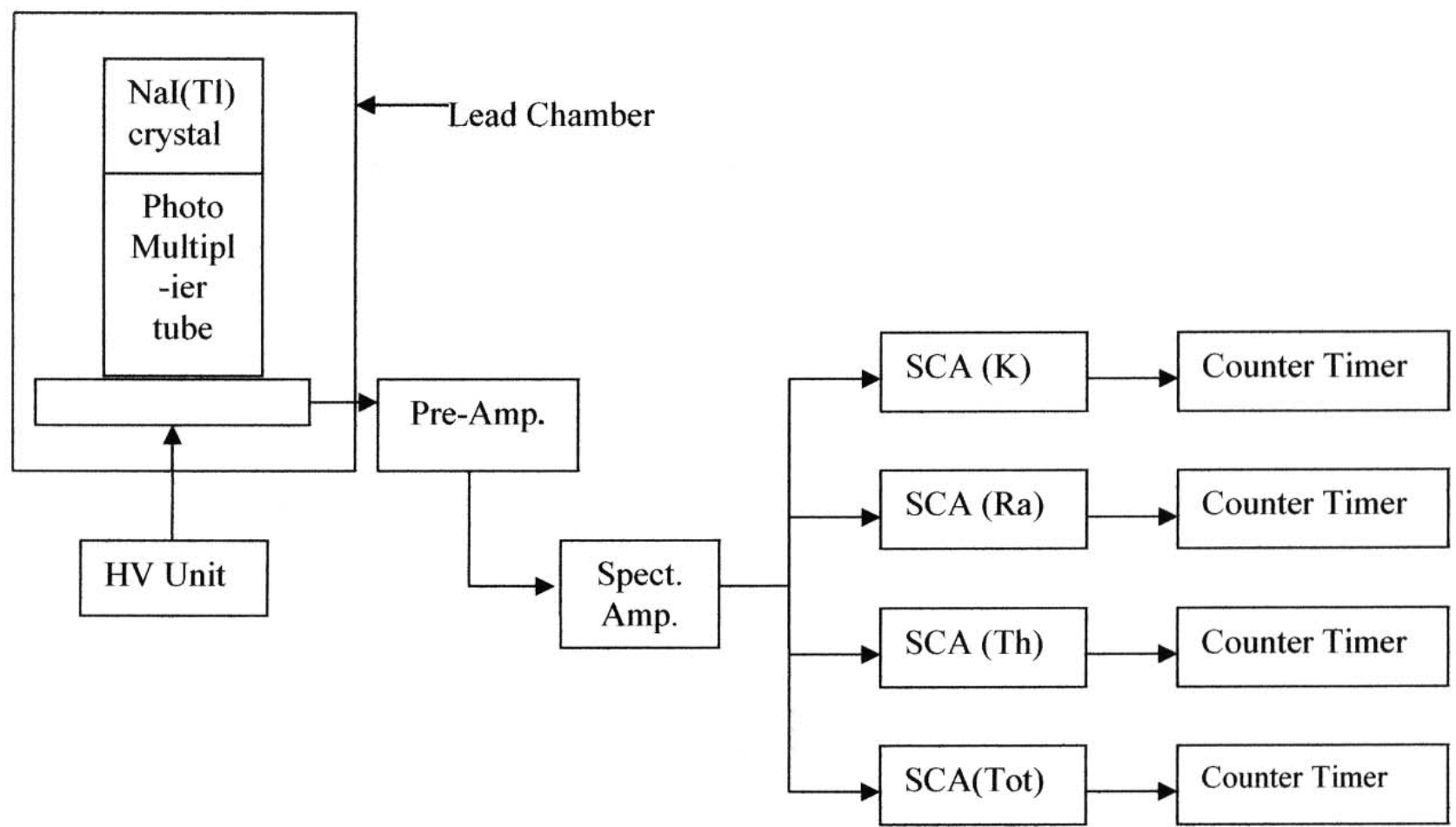

Figure 7. Block diagram of 4-channel spectrometry assembly.

Table 8. Values of standards used and values of stripping factors and sensitivities observed at laboratory.

Standards used at the laboratory: (each of $200 \mathrm{gms}$ ) 1100 ppm $\mathrm{U}_{3} \mathrm{O}_{8}$;

4500 ppm $\mathrm{ThO}_{2}$;

$26.57 \% \mathrm{~K}$

Stripping factors:

$$
\alpha=0.35 ; \beta=0.50 ; \gamma=0.9 ; \mathrm{a}=0.04
$$

Sensitivities:

$\mathrm{K}-\mathrm{Ch} .=95$ counts $/ \% / 200 \mathrm{sec}$.

$\mathrm{Ra}(\mathrm{eU})-\mathrm{Ch} .=7.4$ counts $/ \mathrm{ppm} / 200 \mathrm{sec}$.

$\mathrm{Th}-$ Ch. $=2.3$ counts $/ \mathrm{ppm} / 200 \mathrm{sec}$.

ing stripping factors and sensitivity factors. Then the samples are counted for a fixed time $(3000 \mathrm{sec}$ for low grade $(<100 \mathrm{ppm})$ samples and $600 \mathrm{sec}$ for high grade $(>100 \mathrm{ppm})$ samples $)$ and using the above formulae their concentrations are calculated. The values of the standards used in the laboratory and the stripping factors and sensitivity factors observed in the laboratory are tabulated in table 8.

Uranium series can be broadly divided into two groups: uranium group and radium group, which do not tend to remain in equilibrium. Under favourable climatic and geologic conditions, some of the daughter products of uranium get separated from the parent, causing disequilibrium. In equilibrium conditions, the result of gamma ray spectrometry e.g., $\mathrm{Ra}(\mathrm{eU})$ will correlate with the actual uranium expressed by $\mathrm{U}(\beta-\gamma)$, whereas in disequilibrium conditions, they may not correlate. Hence, the measurement of actual uranium is required, which is done using $\beta-\gamma$ technique. Thorium series remains in equilibrium for all practical purposes. 


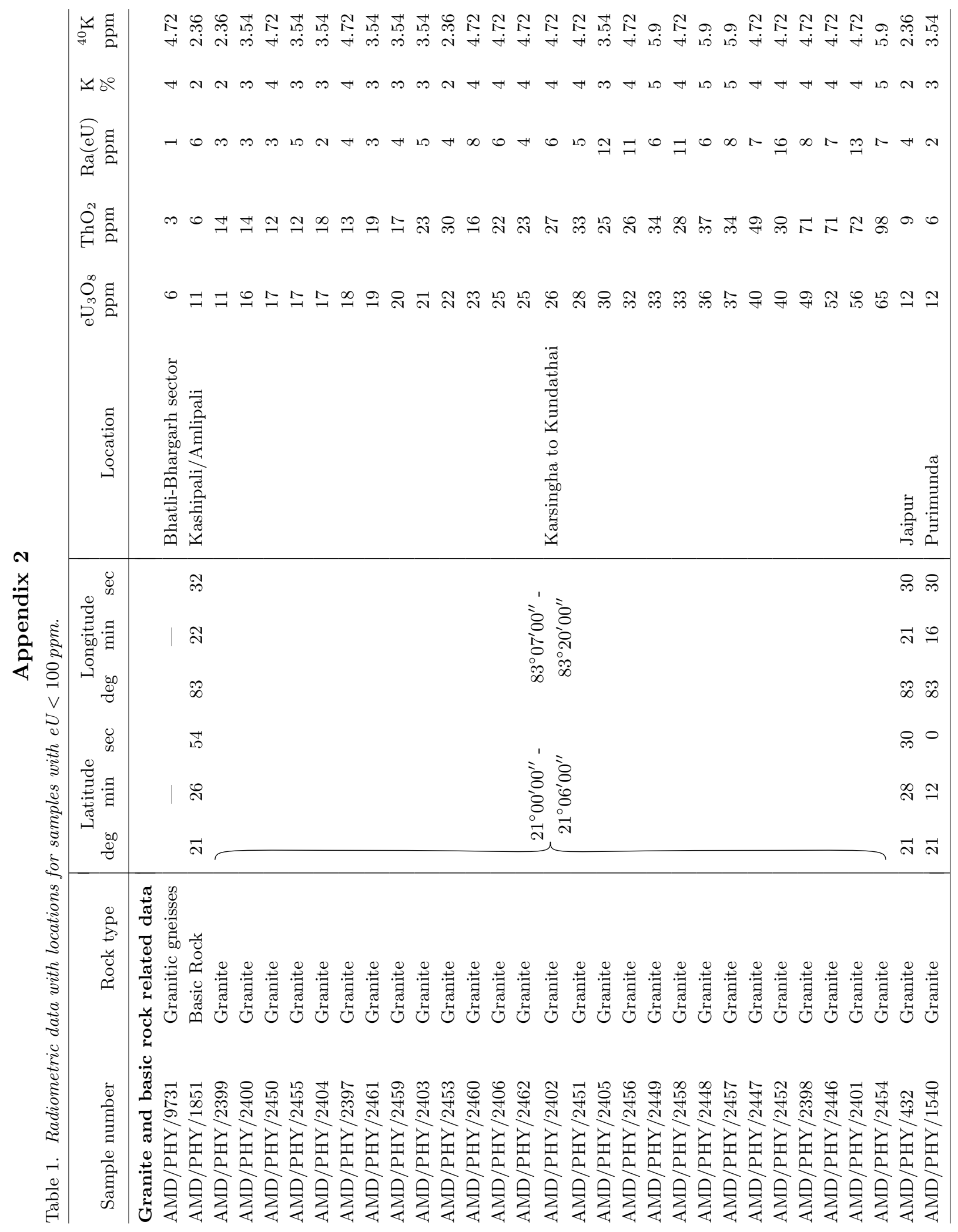




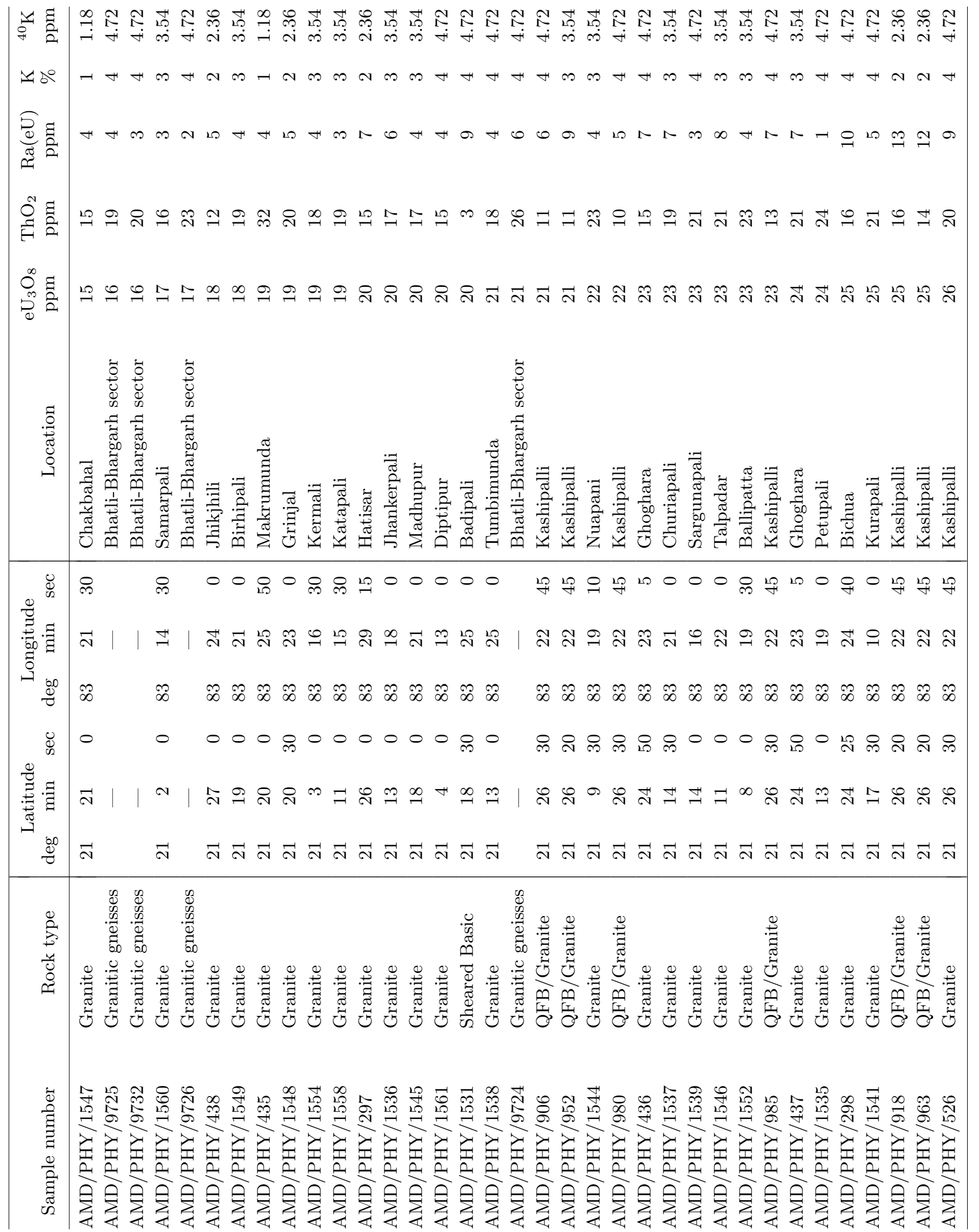


幽药

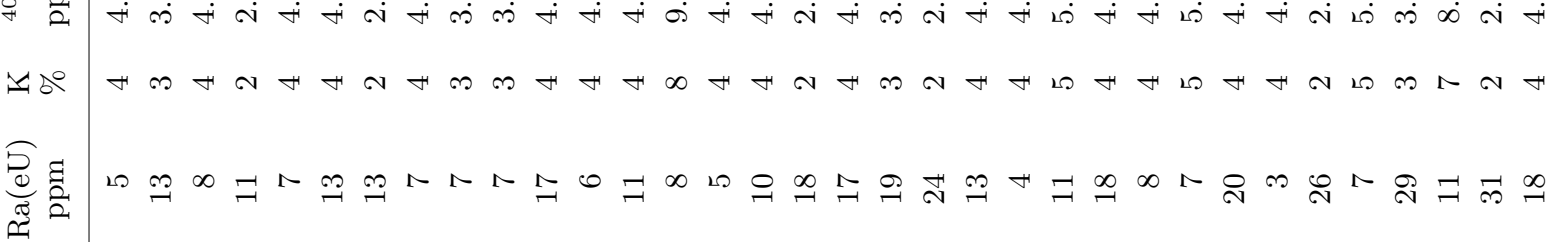

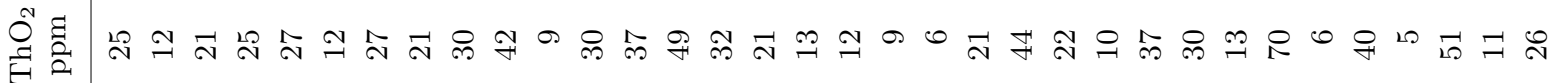
啰范

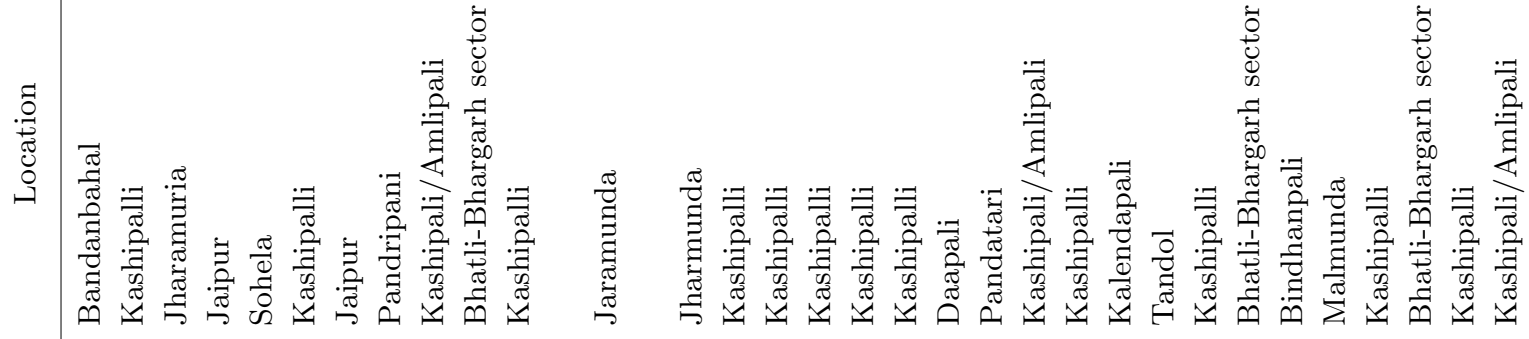

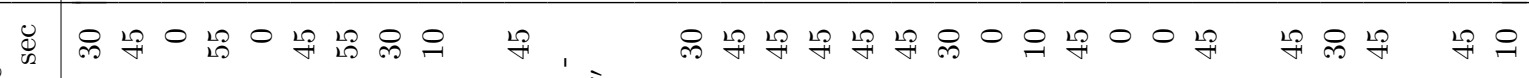
䓯: 車

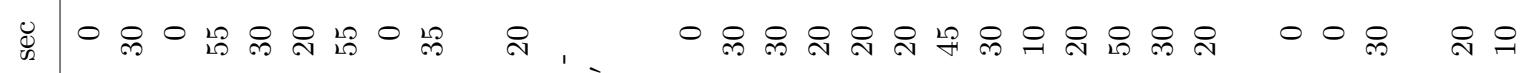

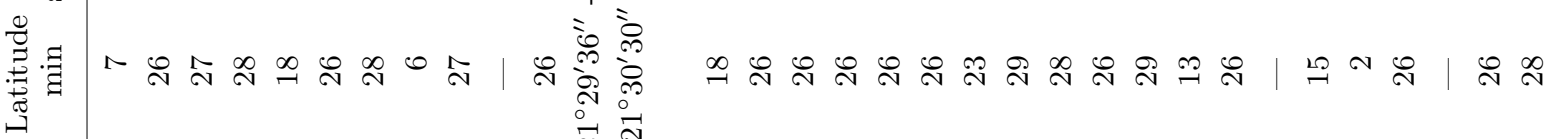

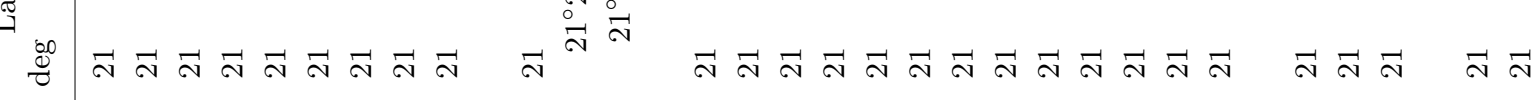

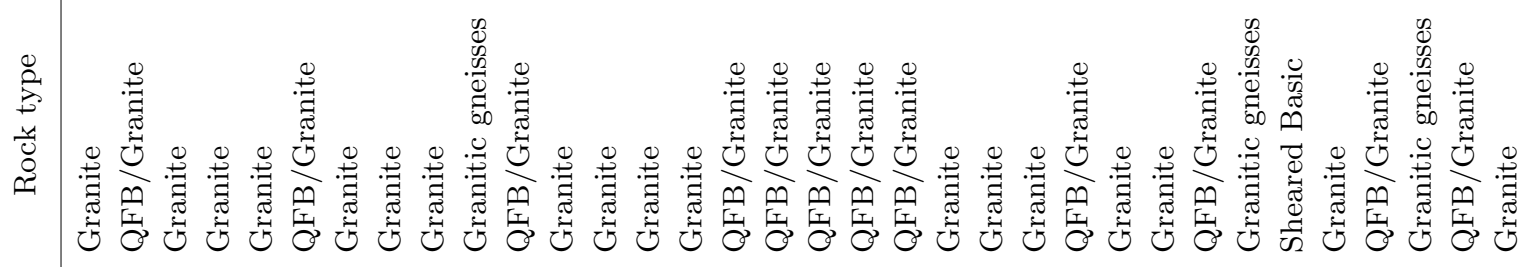

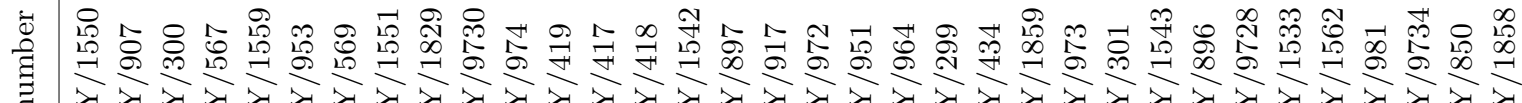

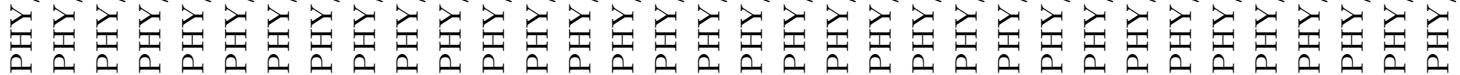

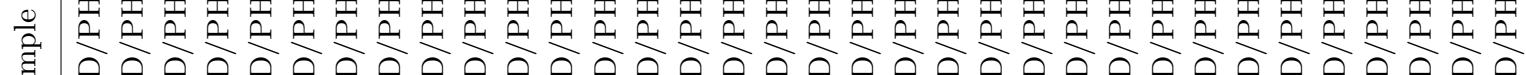

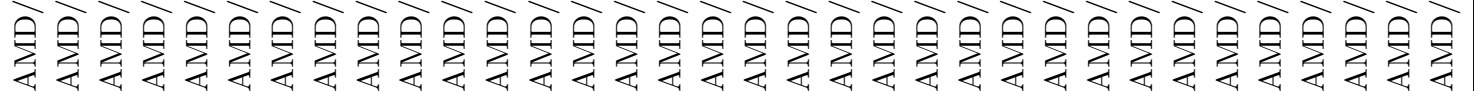


|

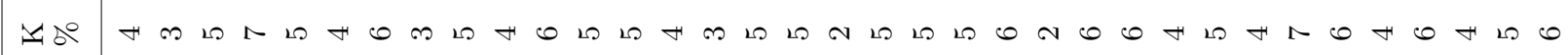

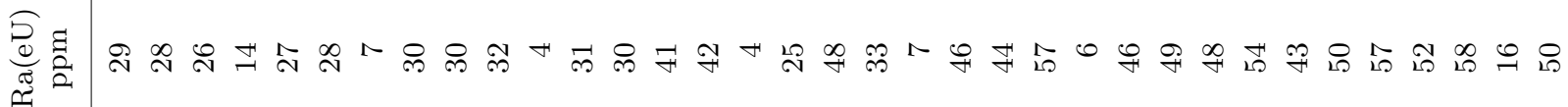

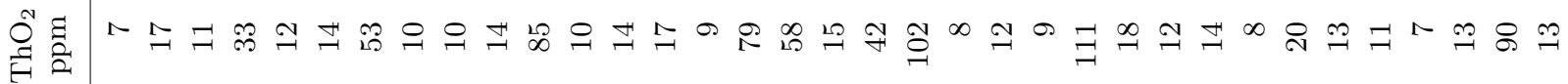

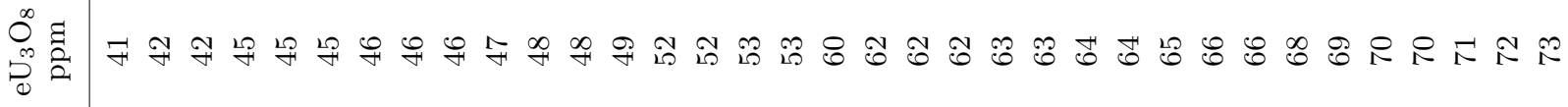

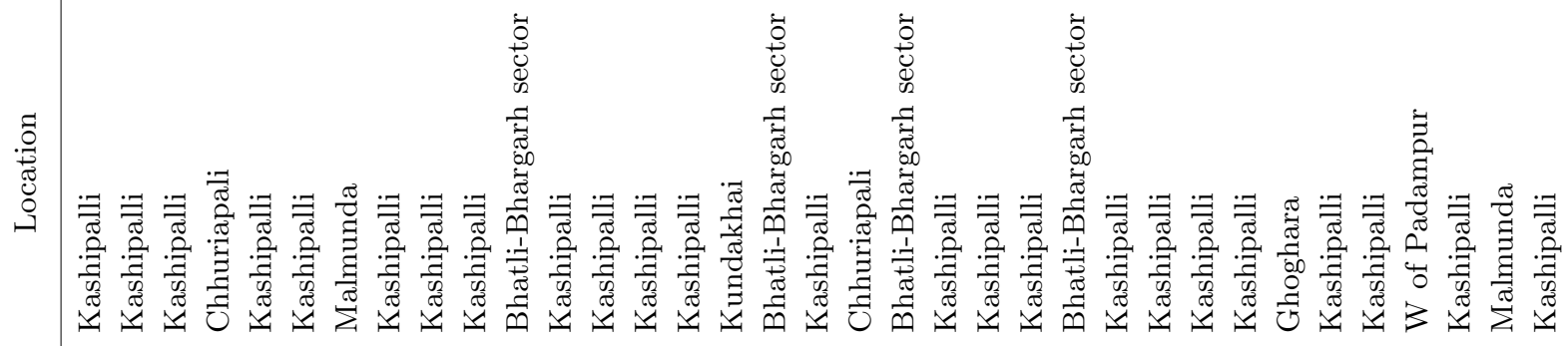

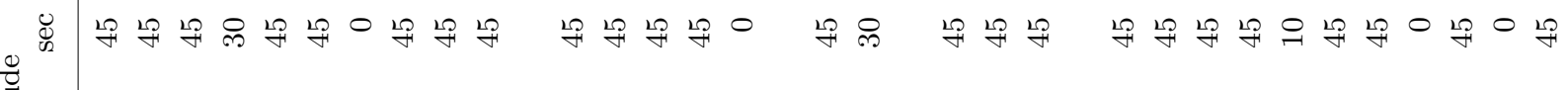

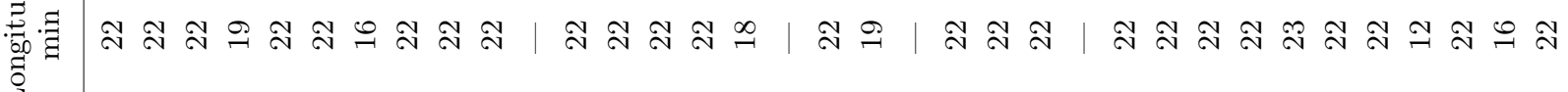

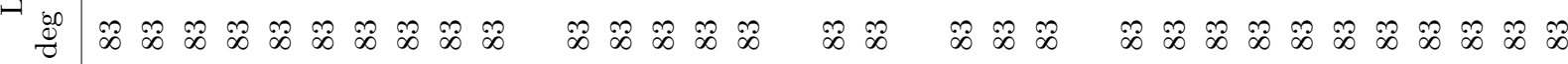

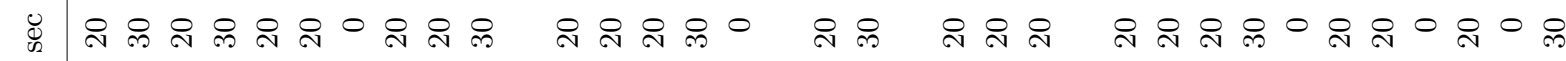
莺

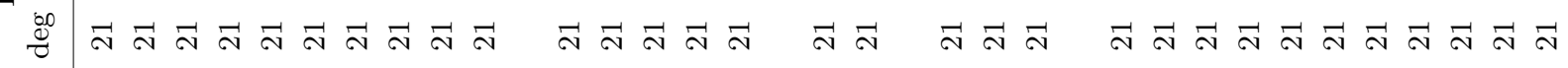

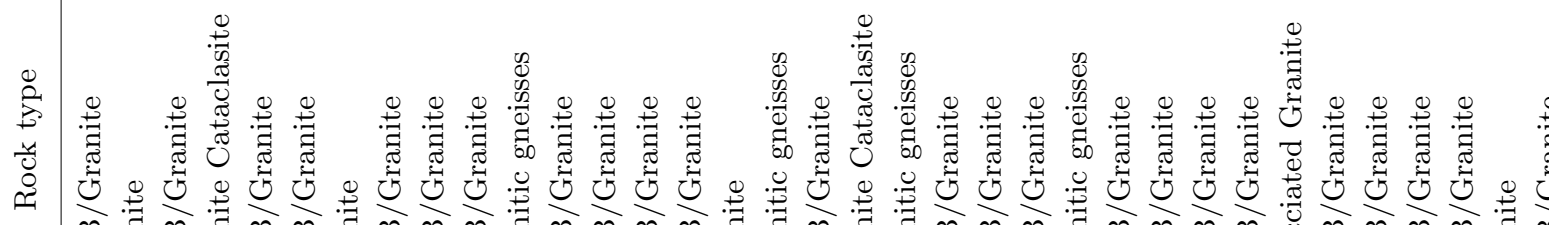
冈

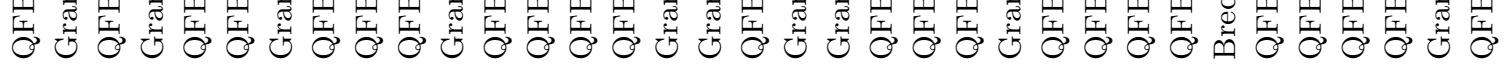

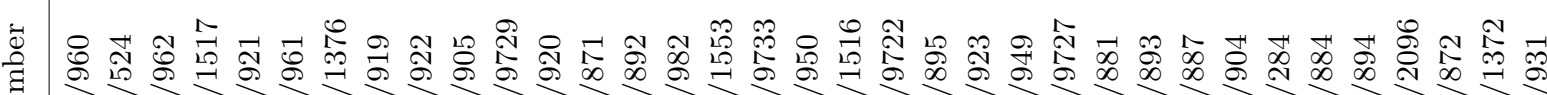

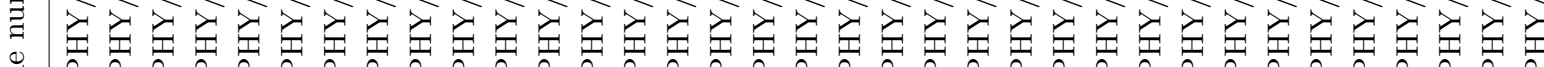

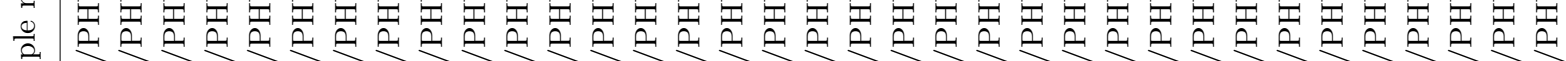

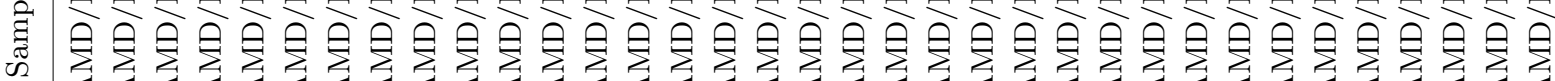




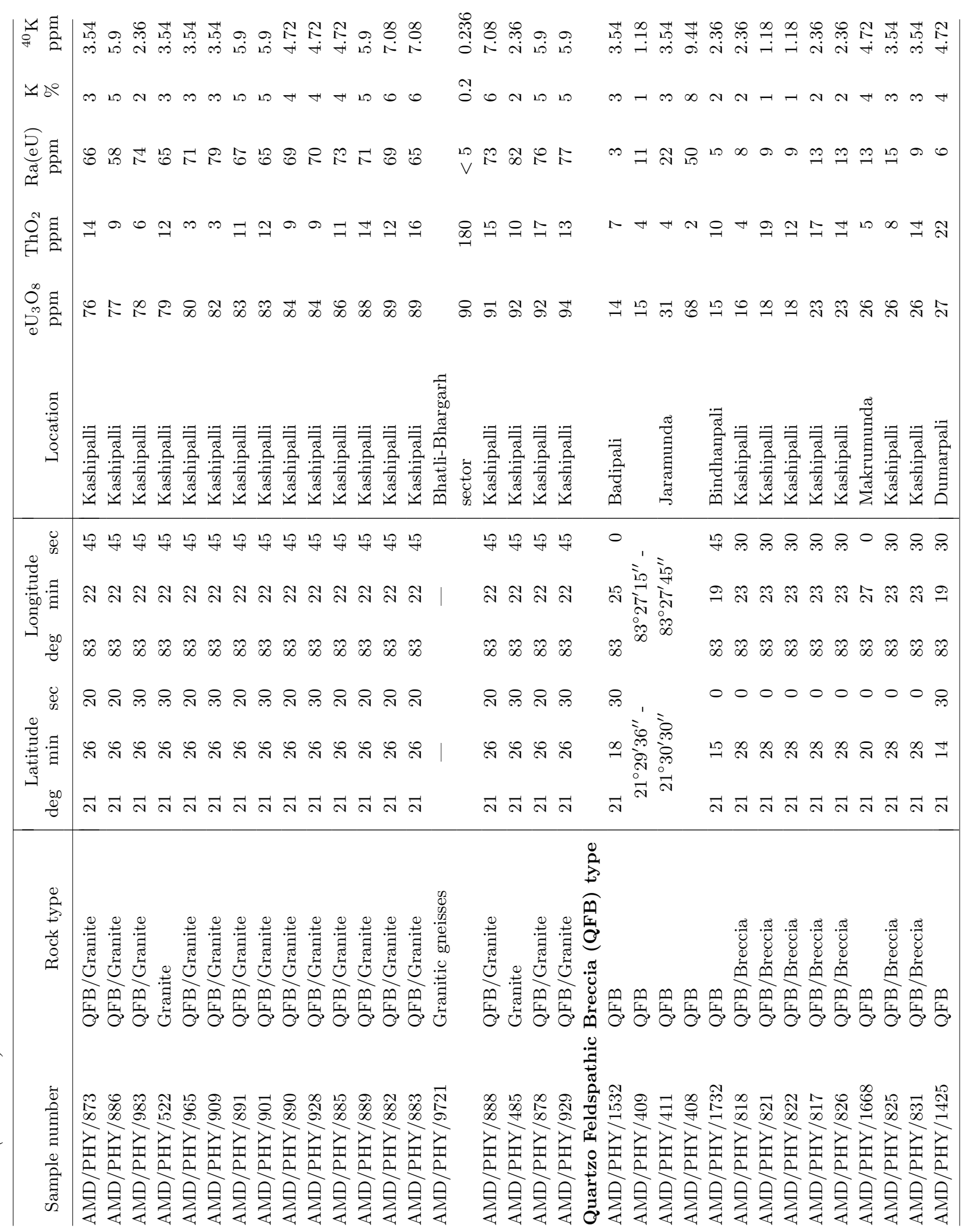




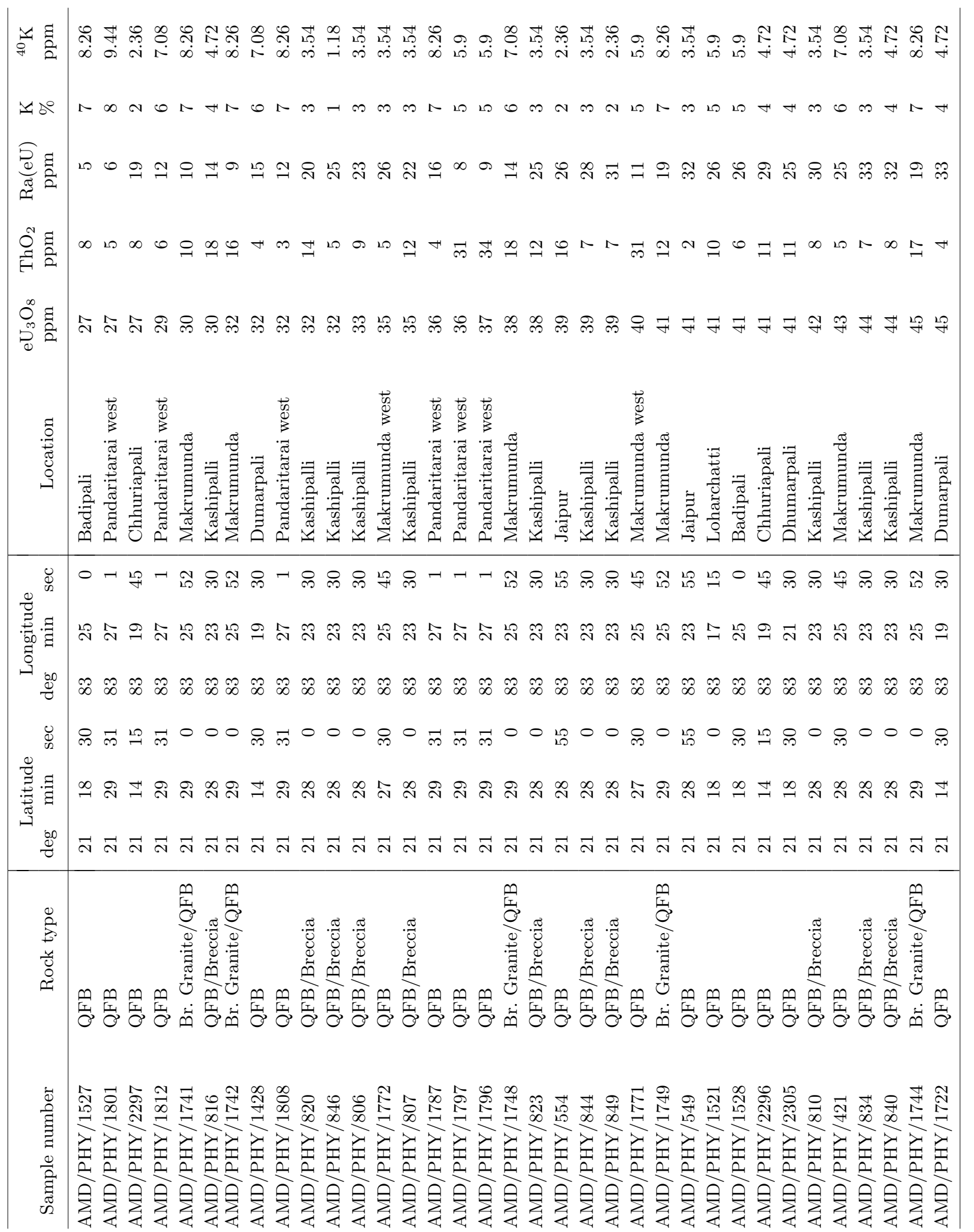




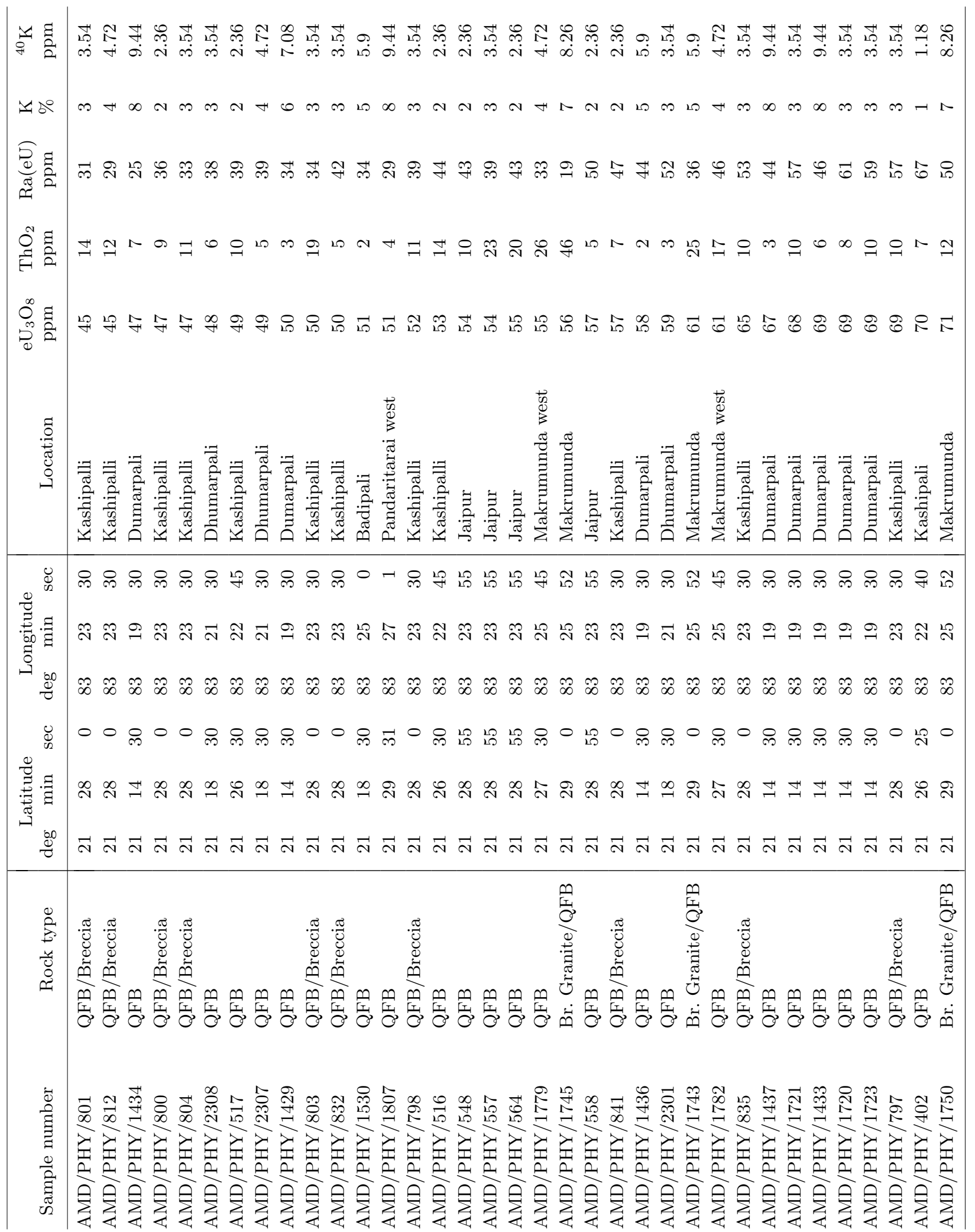




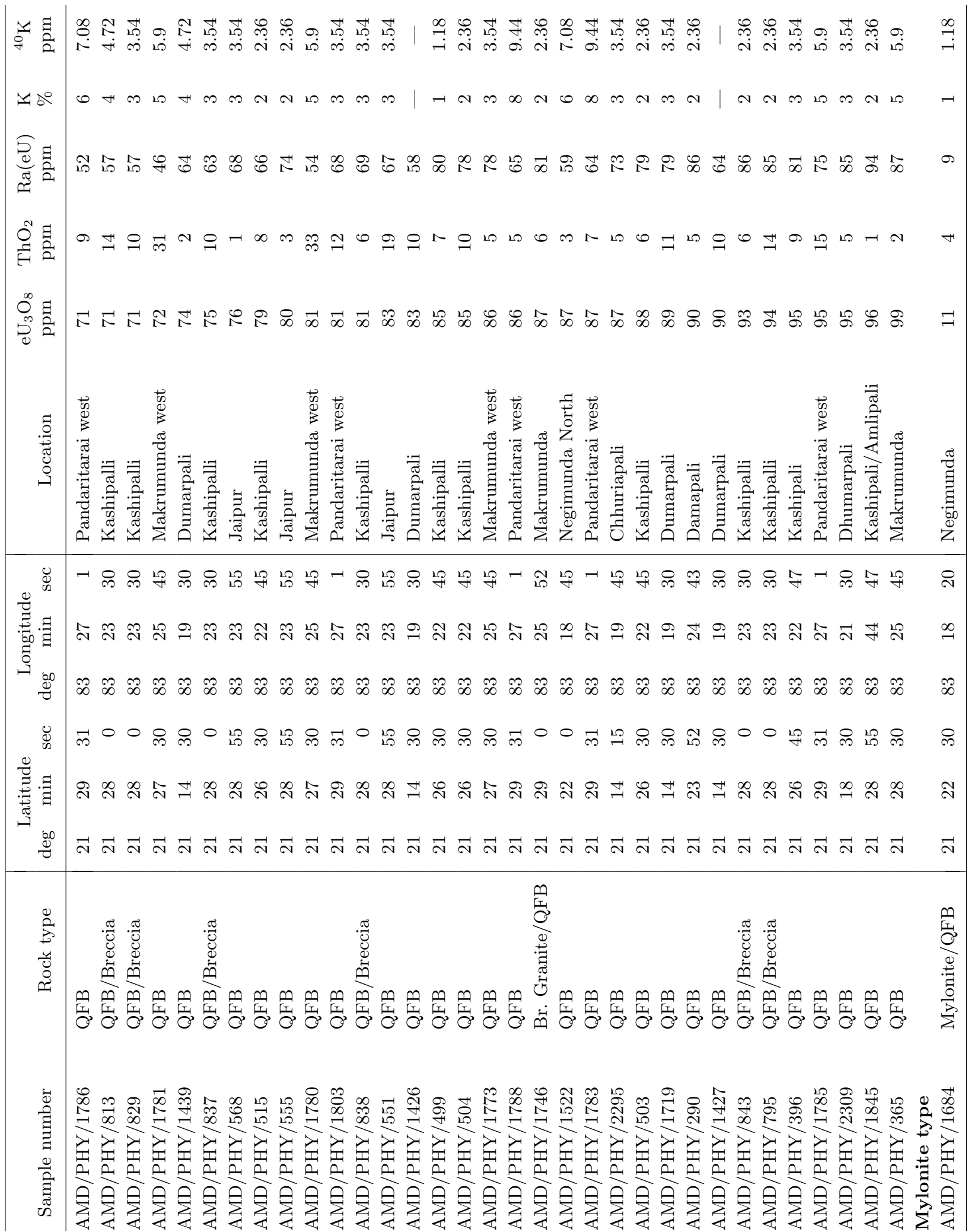




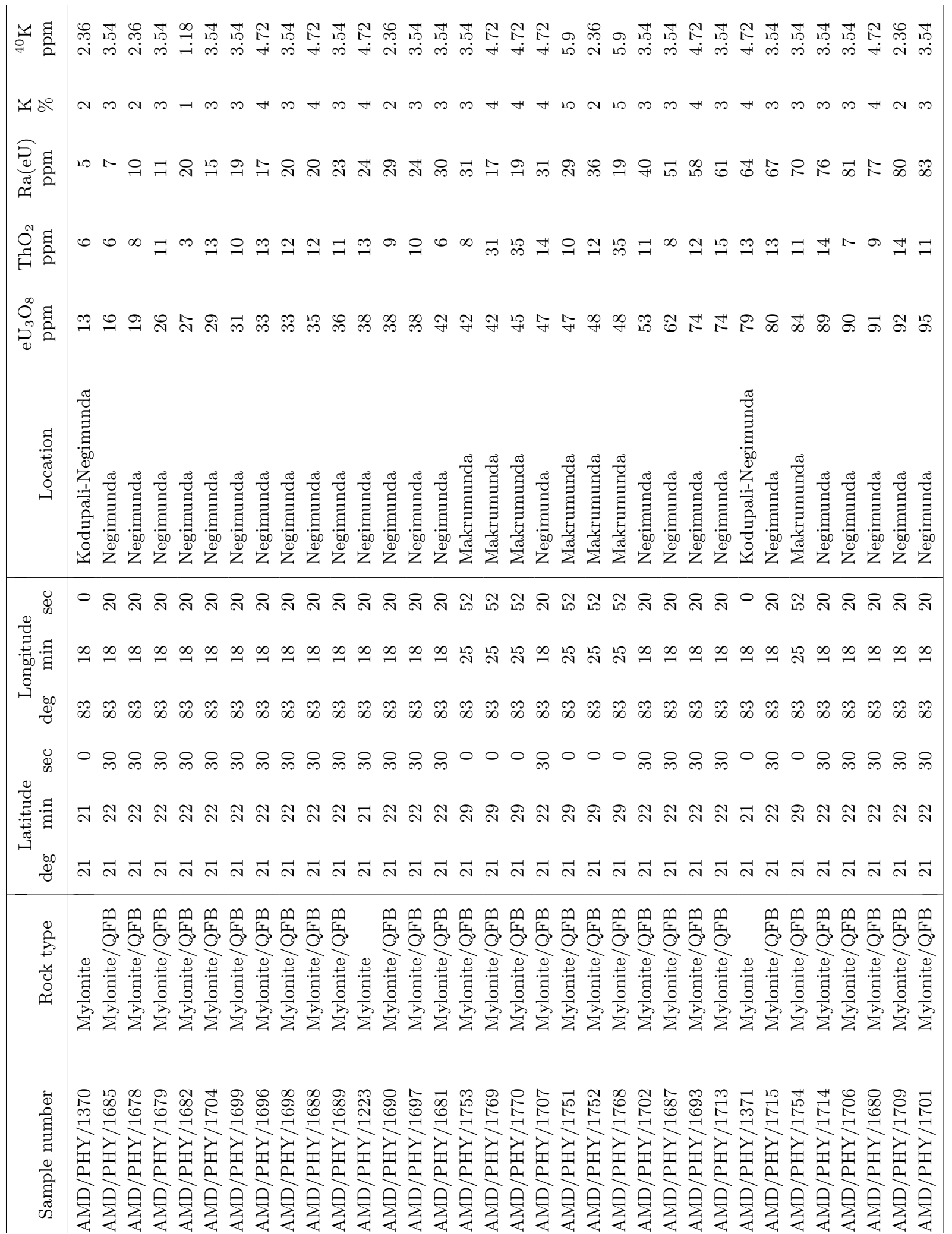




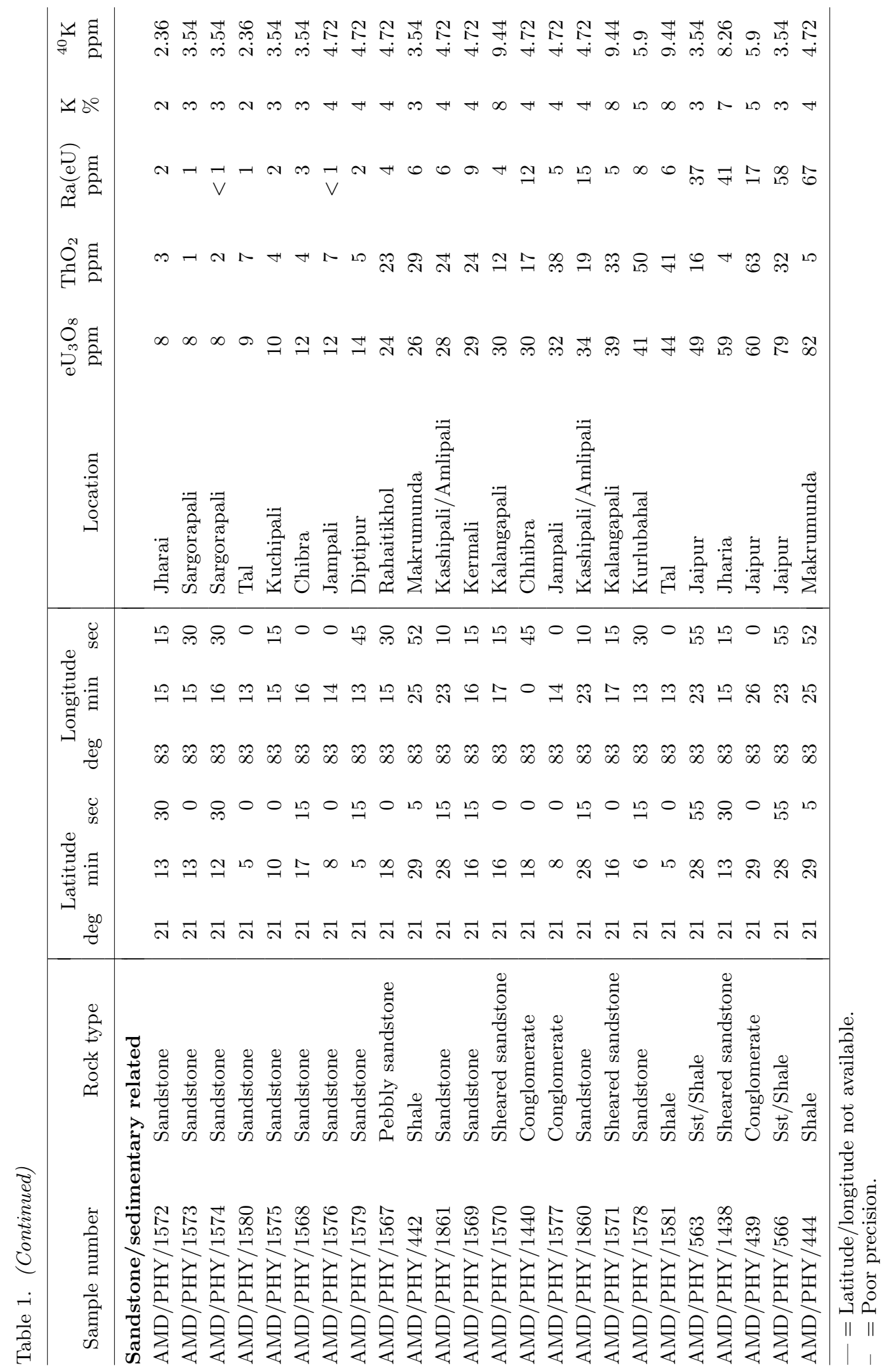




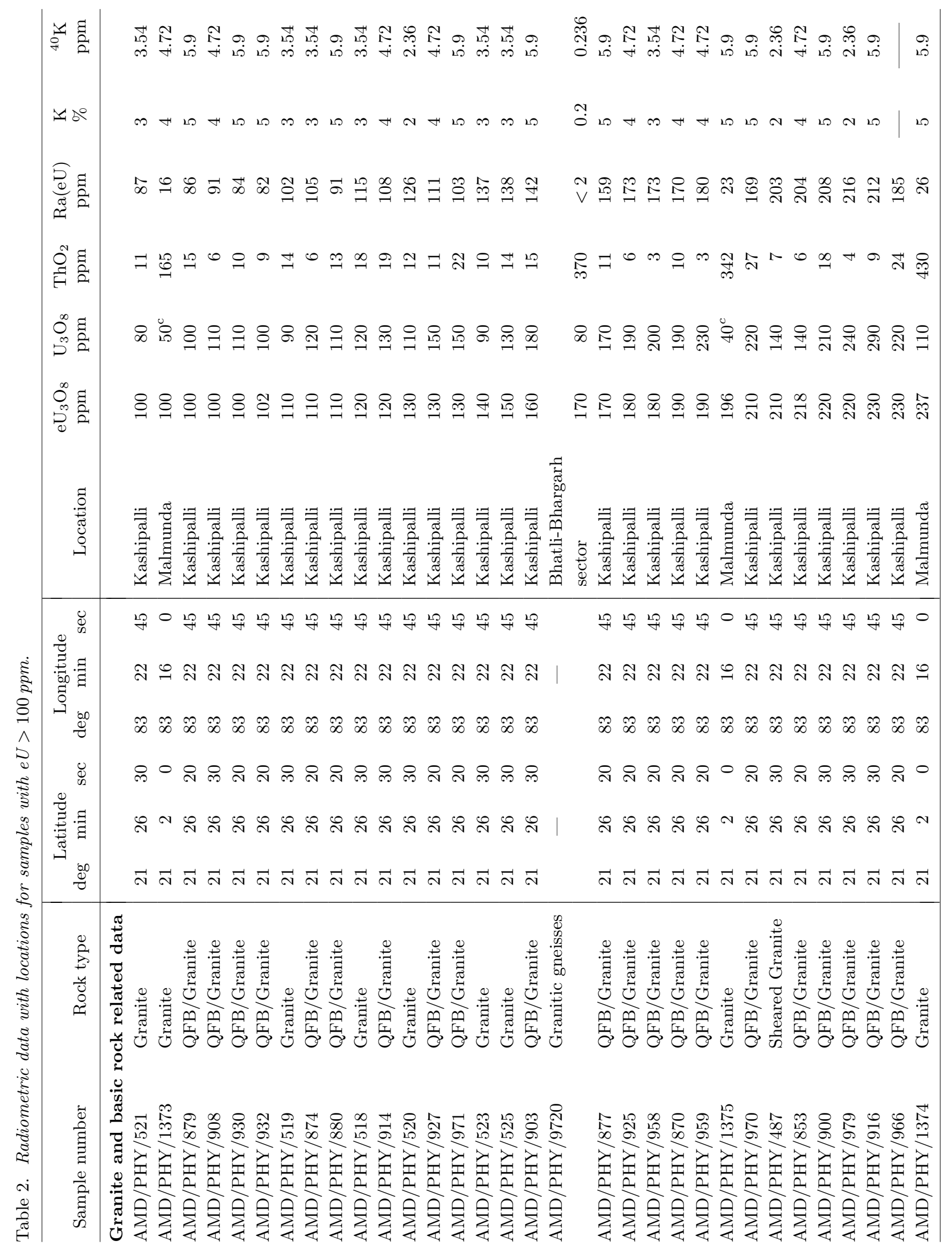




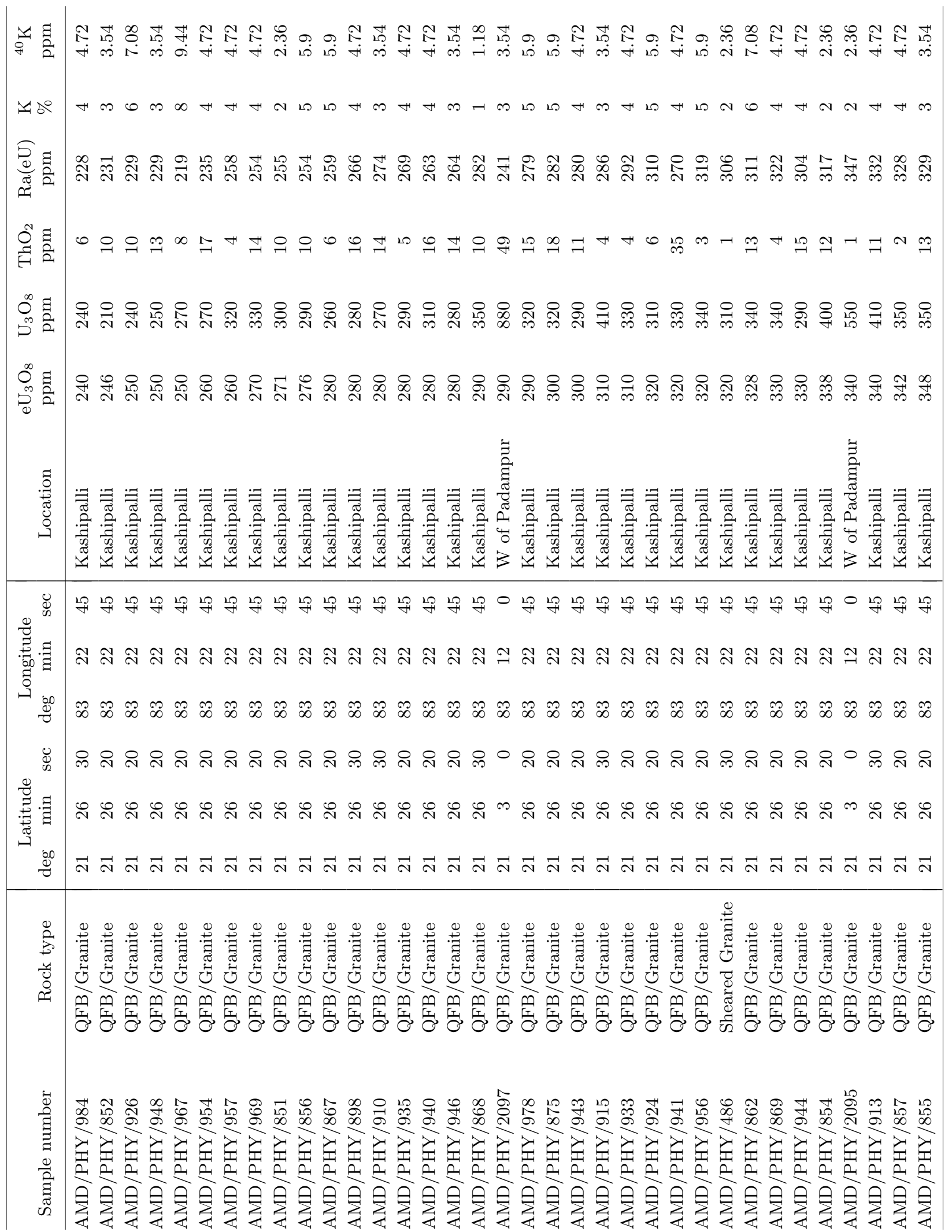




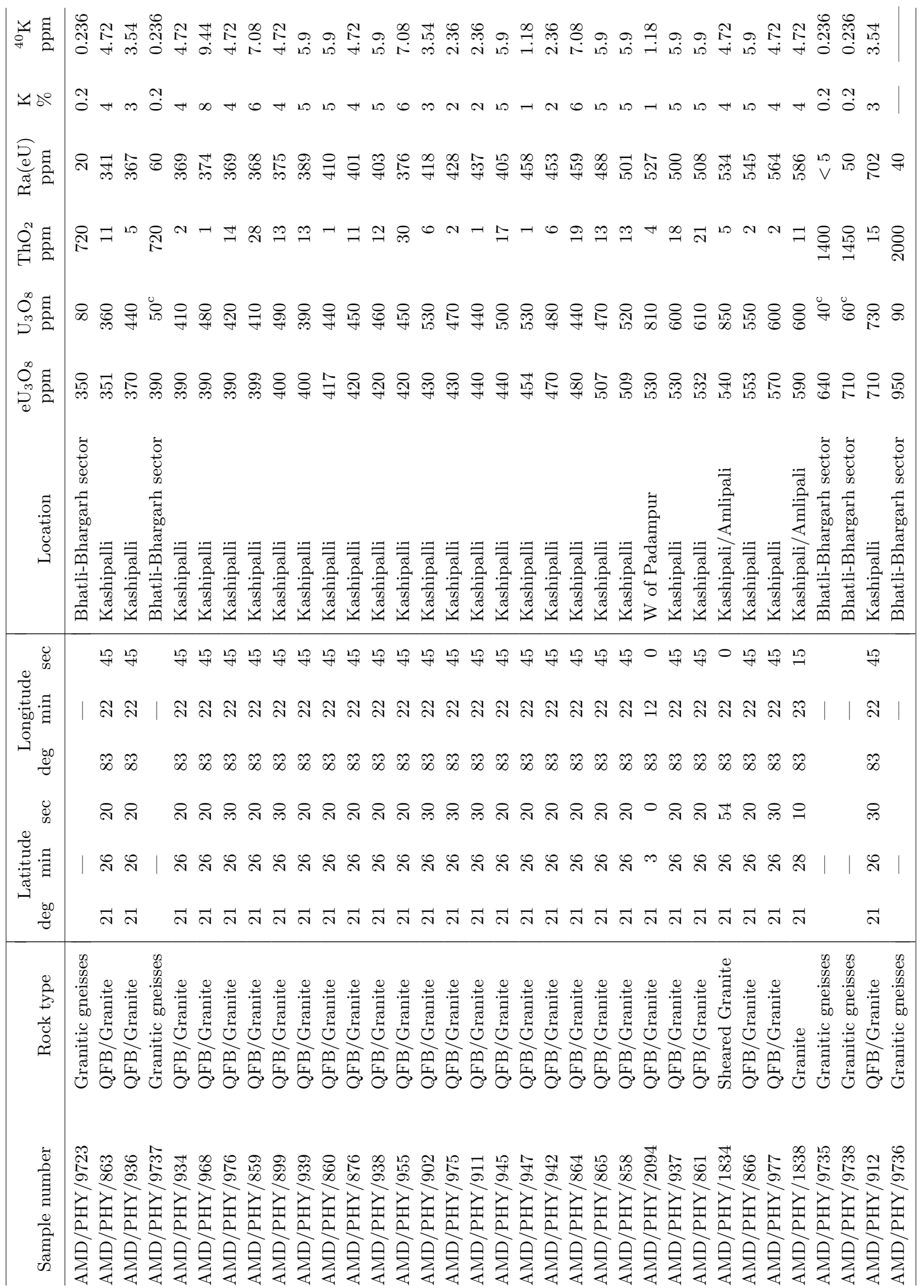




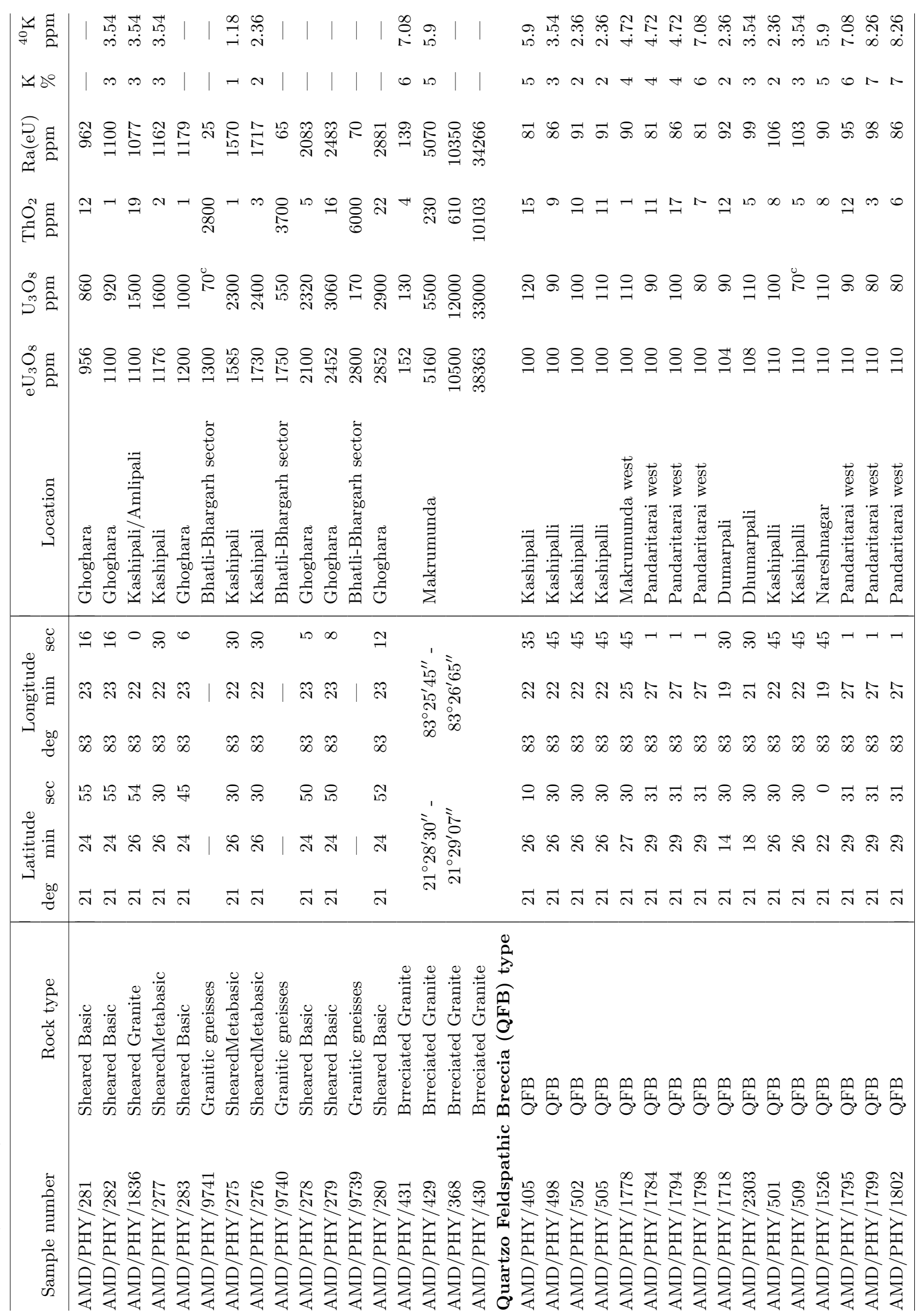




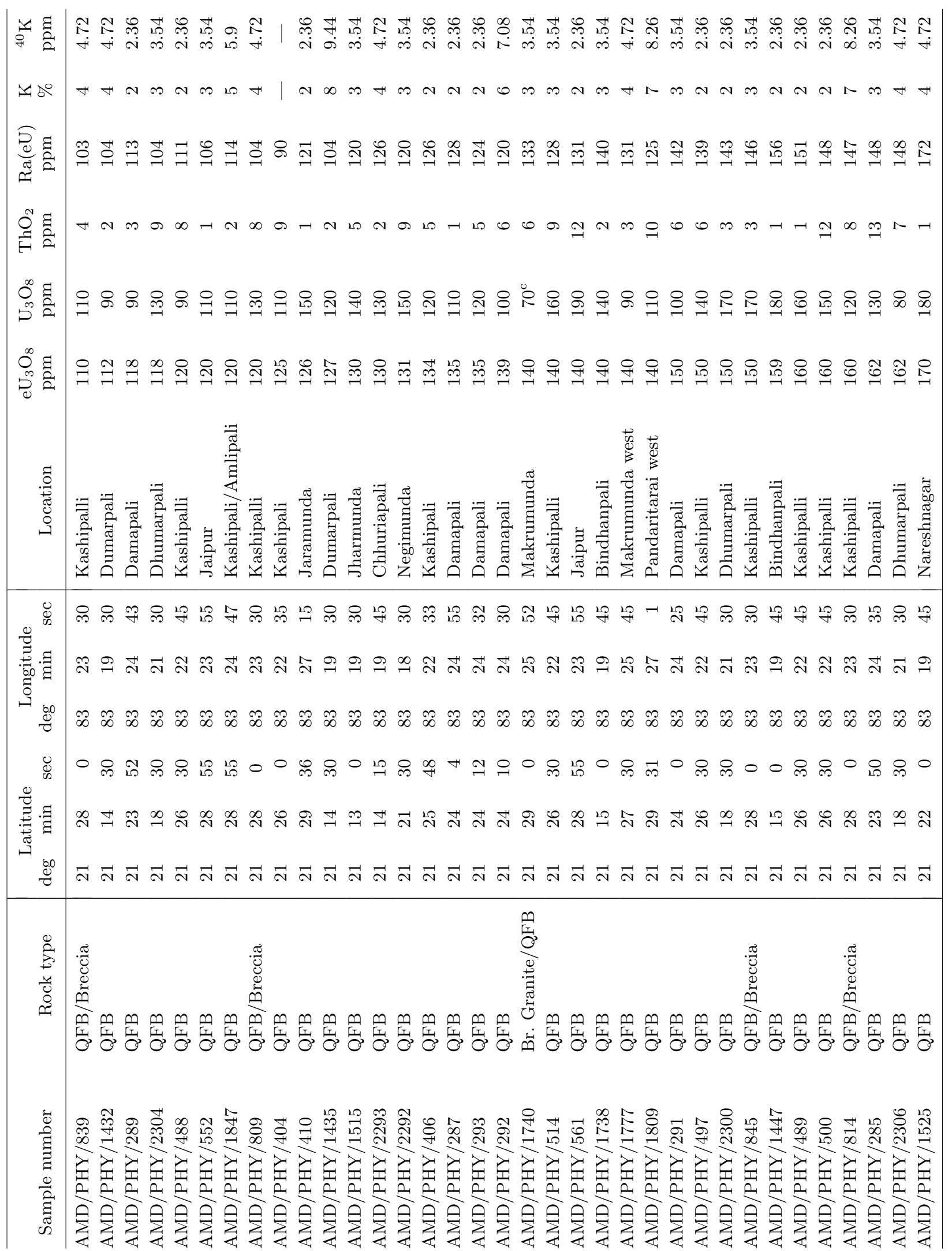




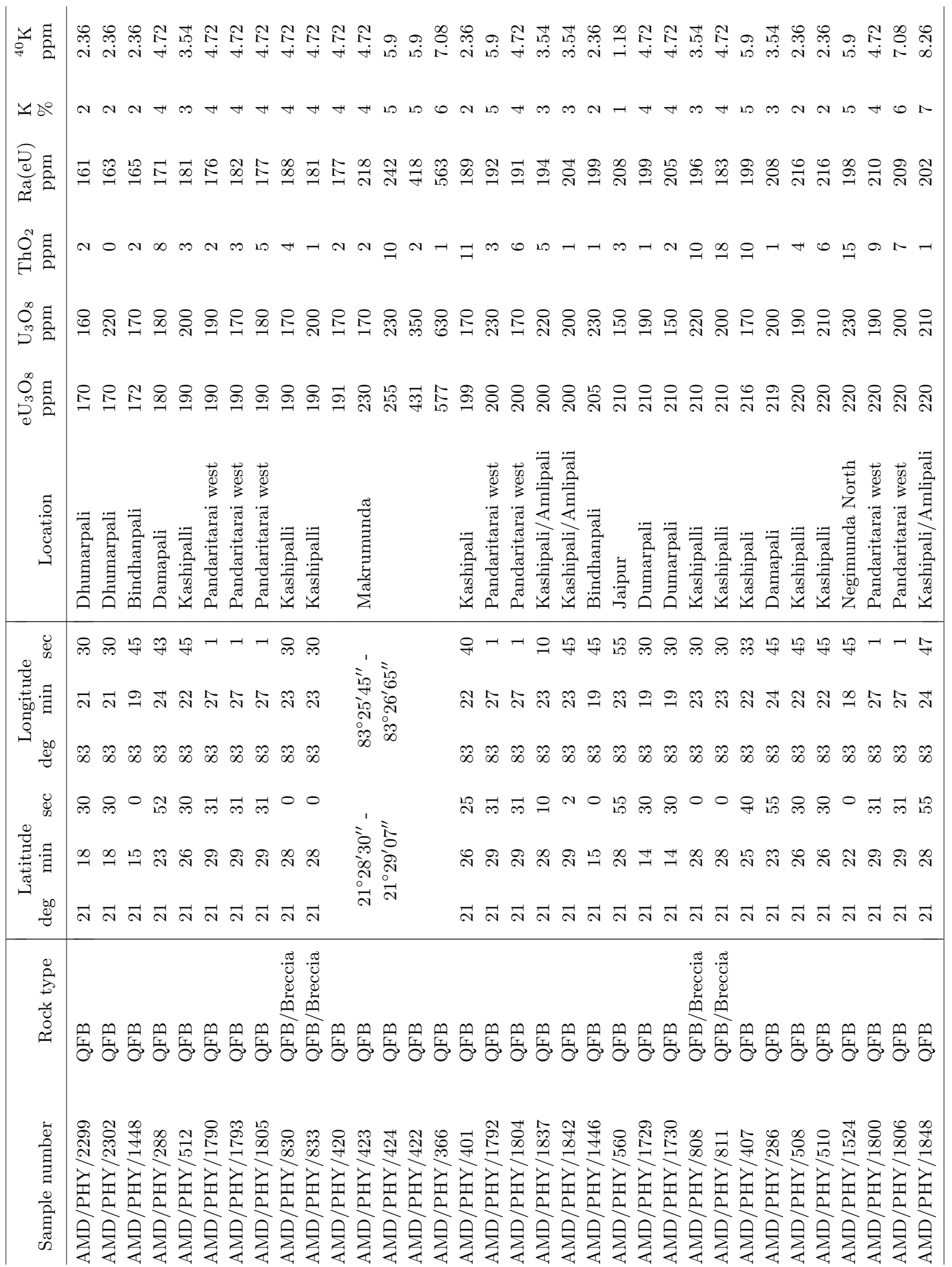




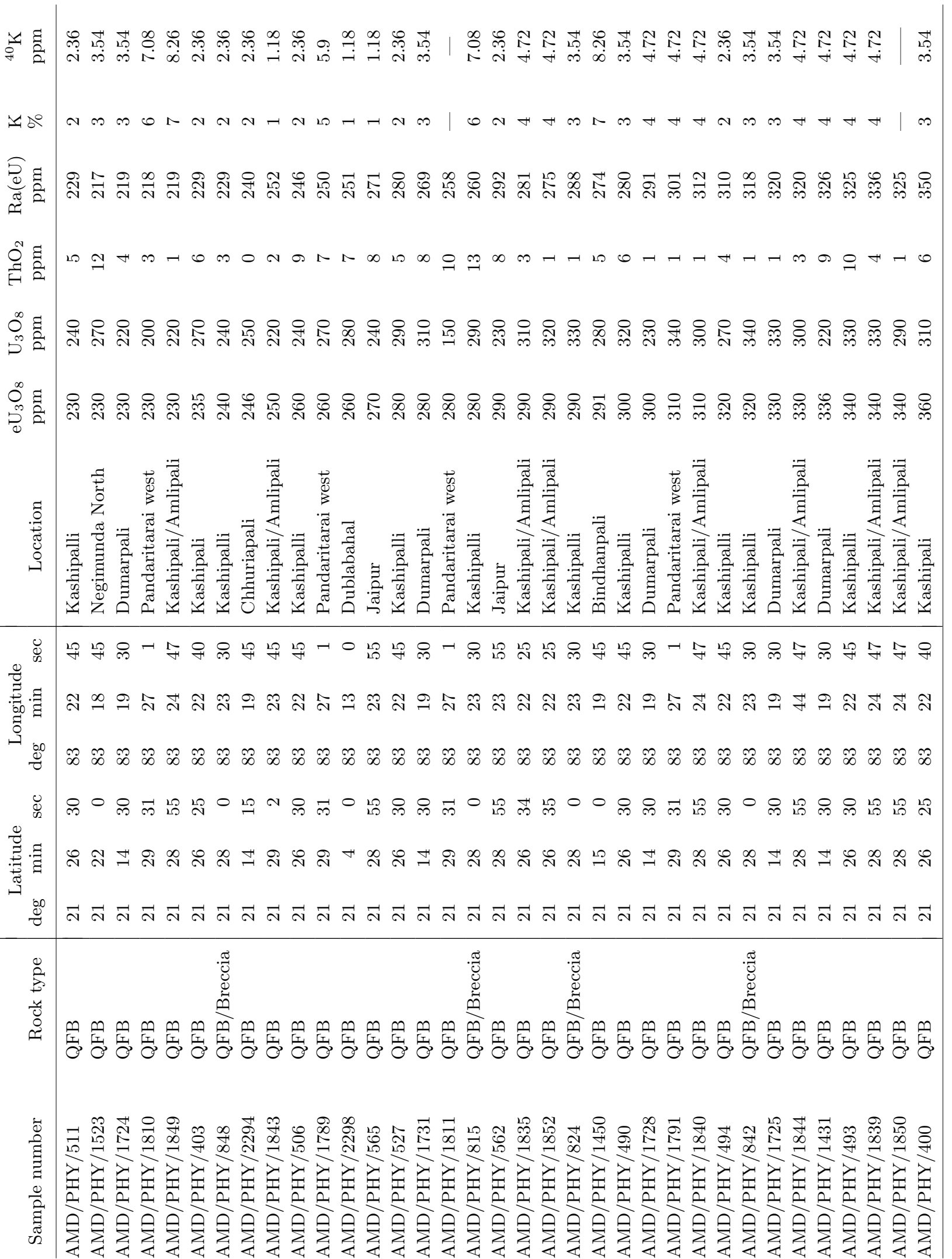




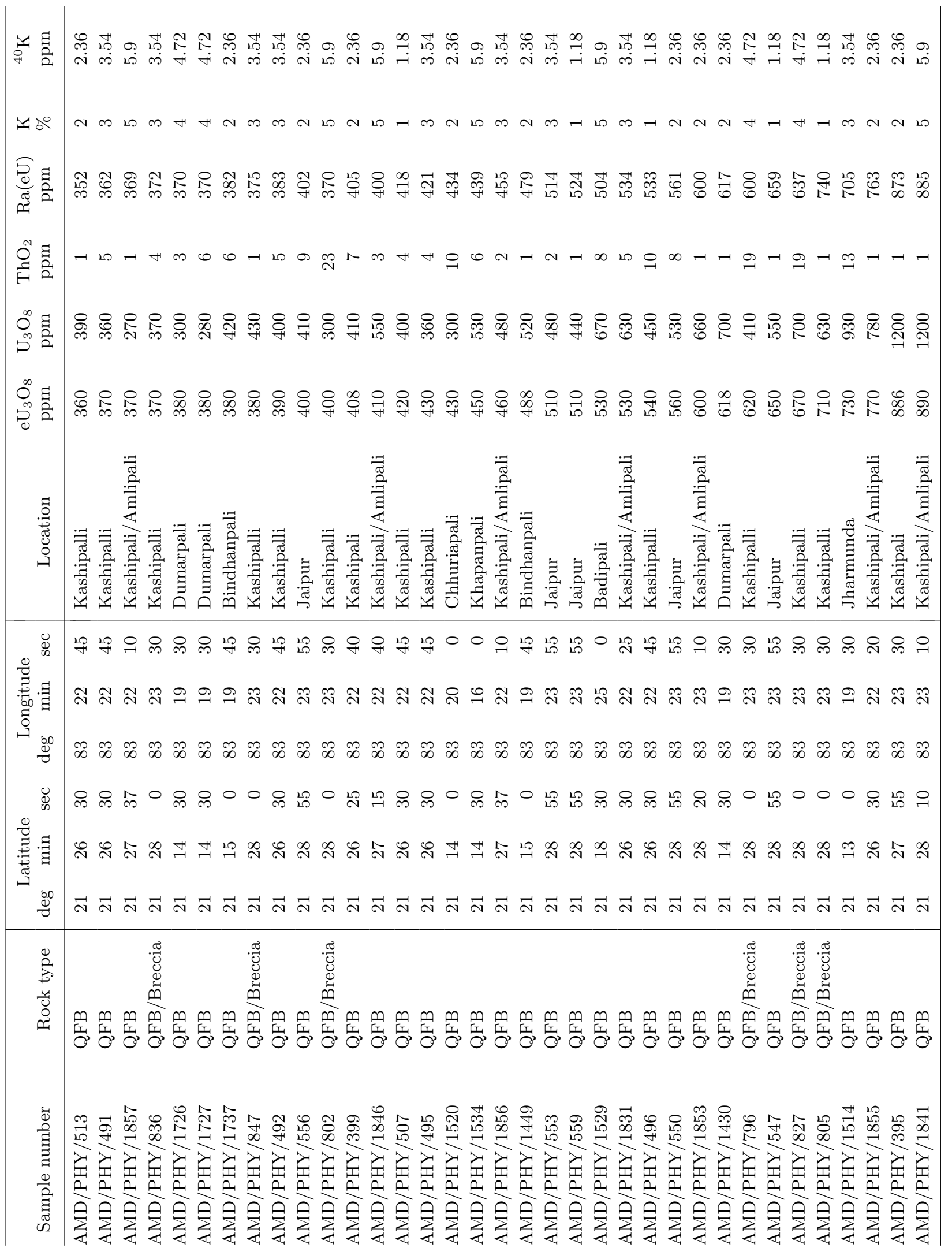




\begin{tabular}{|c|c|c|}
\hline 完 & 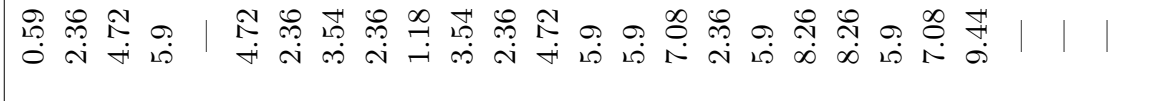 & 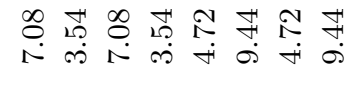 \\
\hline & 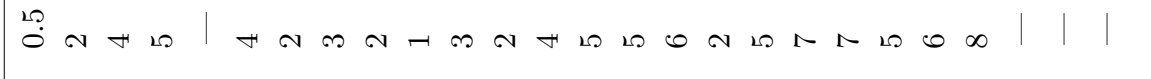 & 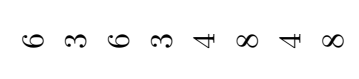 \\
\hline : & 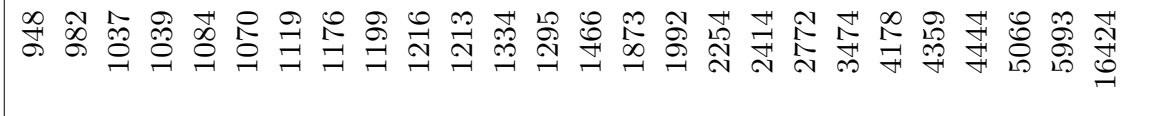 & 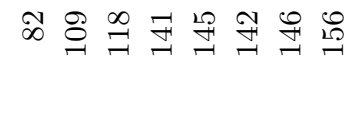 \\
\hline 气ิ & 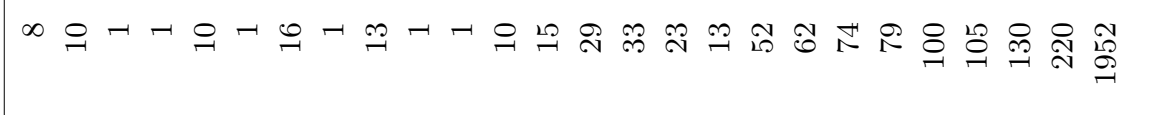 & $\sigma=\infty \sigma \wedge \wedge$ \\
\hline ถี & 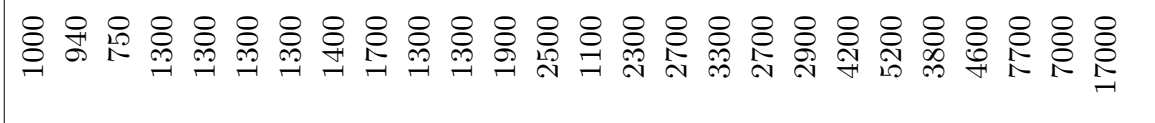 & 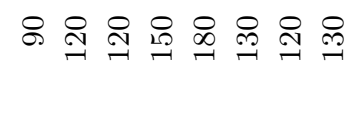 \\
\hline ڤे. & 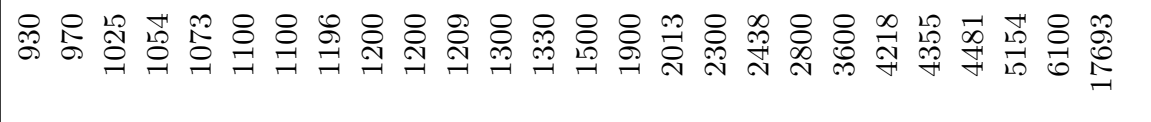 & 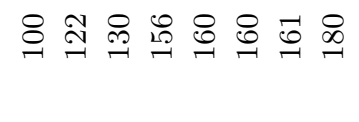 \\
\hline 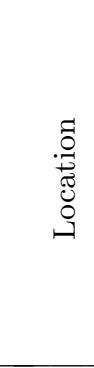 & 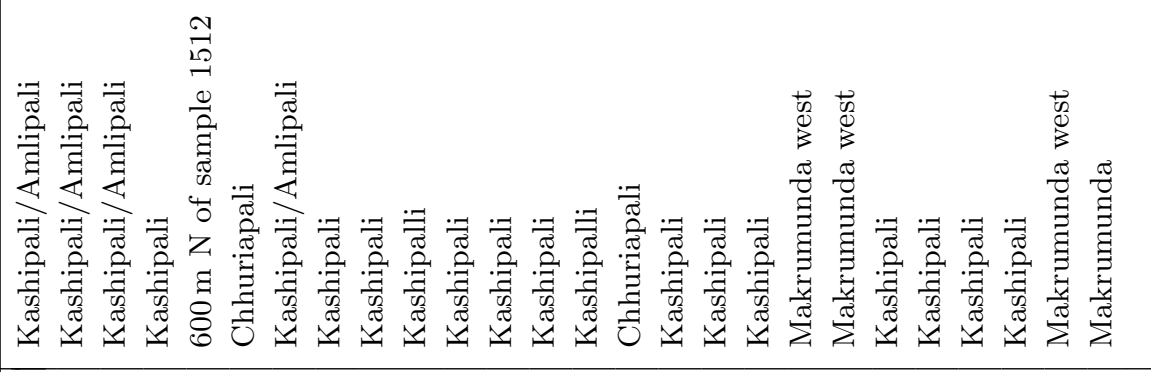 & 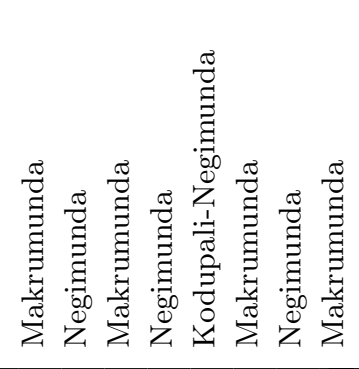 \\
\hline & 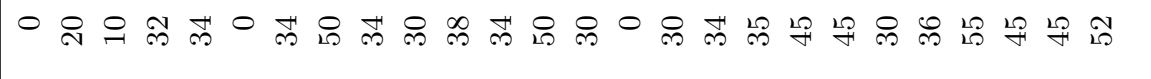 & ำ กิ กิ จำ ำ ำ ำ \\
\hline 总. 者 & 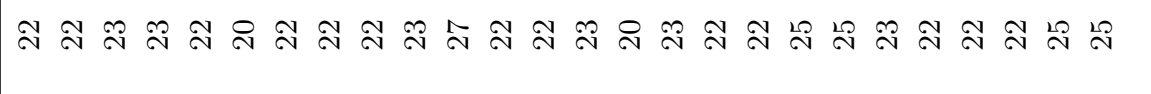 & $\stackrel{\infty}{\sim} \stackrel{\infty}{\sim} \stackrel{2}{\sim} \stackrel{\infty}{\sim} \stackrel{\infty}{\sim} \stackrel{\infty}{\sim} \stackrel{\infty}{\sim}$ \\
\hline$\stackrel{\infty}{0}$ & 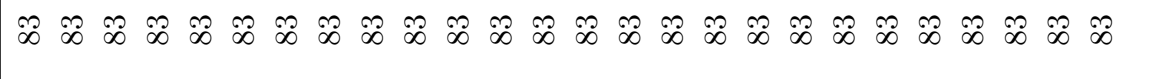 & 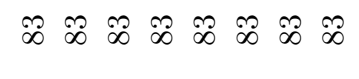 \\
\hline & 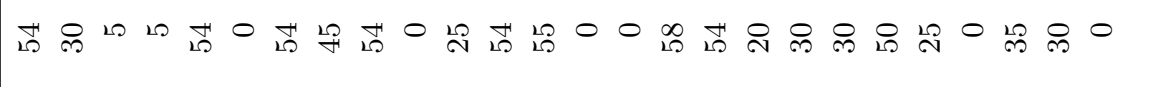 & 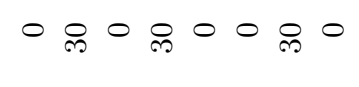 \\
\hline 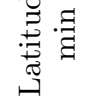 & 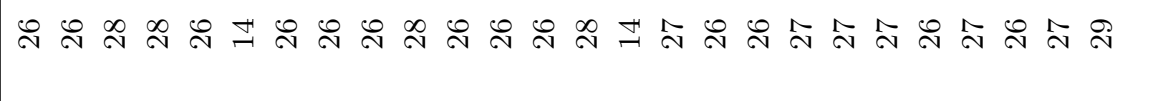 & 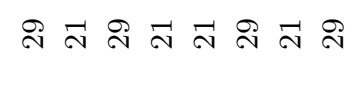 \\
\hline$\stackrel{8}{8}$ & $\vec{\lambda} \vec{N} \vec{N} \vec{N} \vec{N} \vec{N} \vec{N} \vec{N} \vec{N} \vec{N} \vec{N} \vec{N} \vec{N} \vec{N} \vec{N} \vec{N} \vec{N} \vec{N} \vec{N} \vec{N} \vec{N} \vec{N} \vec{N}$ & $\vec{N} \vec{N} \vec{N} \bar{\sigma}$ \\
\hline 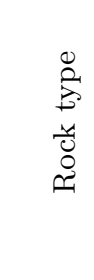 & 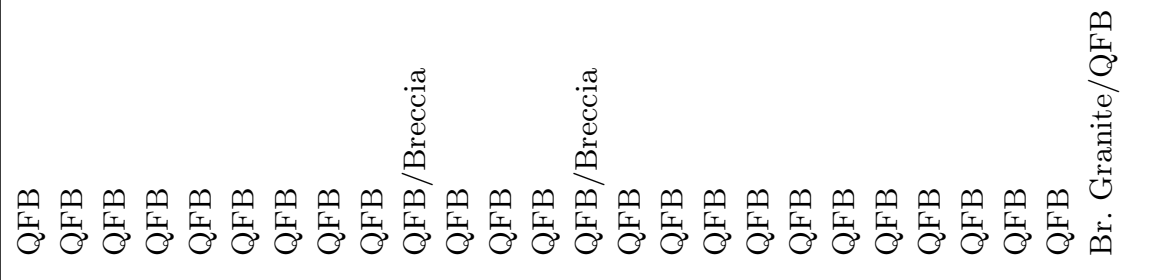 & 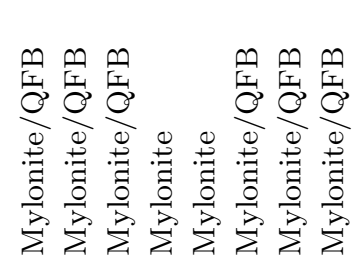 \\
\hline (1) & 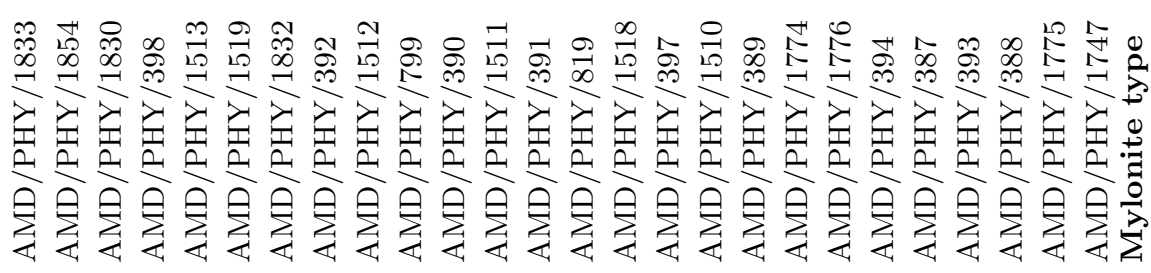 & $\frac{d}{5}$ \\
\hline
\end{tabular}




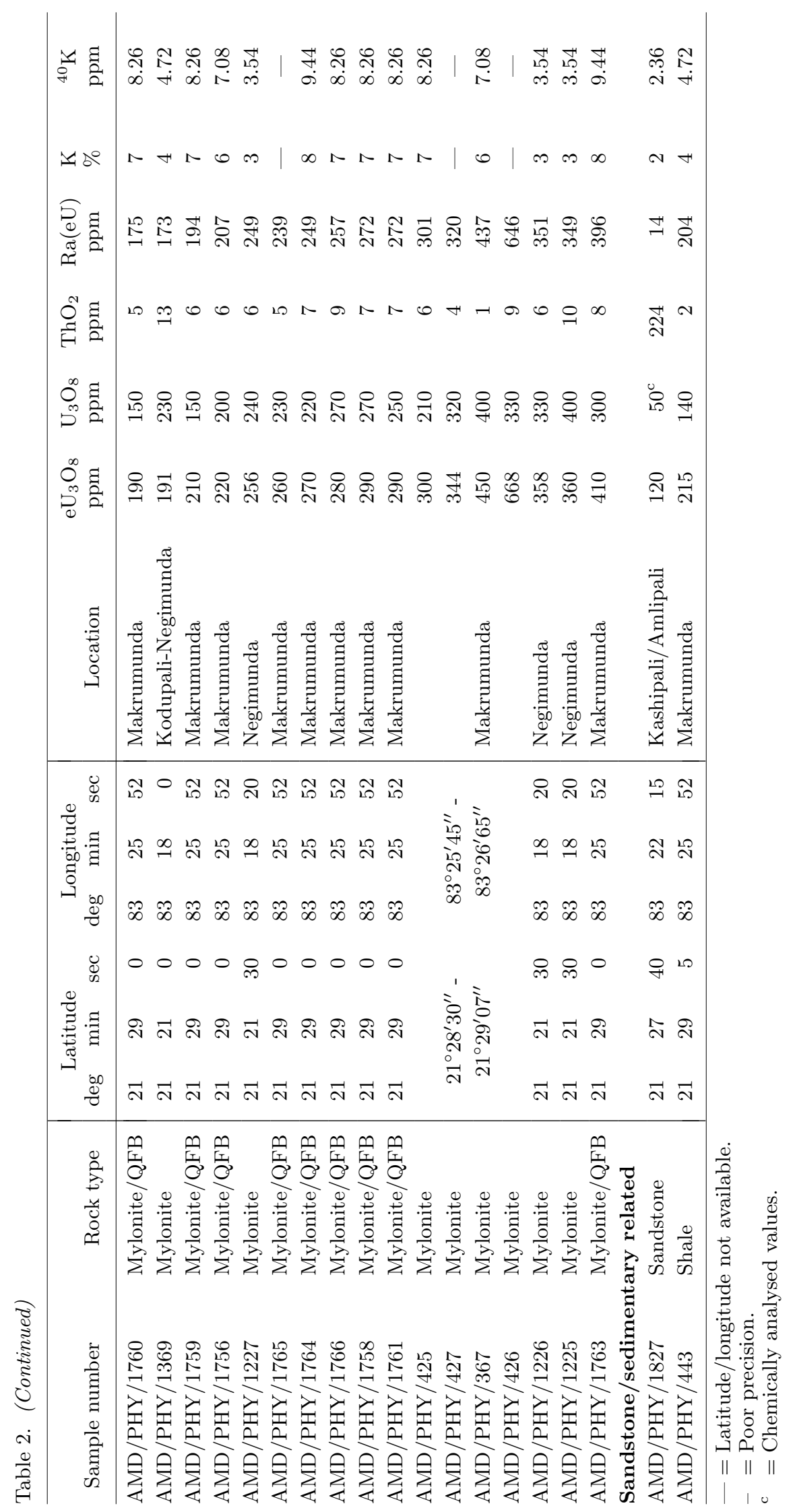




\section{References}

Barker F 1979 Trondhjemite: Definition, environment and hypothesis of origin. In: Trondhjemites, dacites and related rocks, F Barker (ed.), (Amsterdam: Elsevier) pp. $1-12$

Eichholz G G, Hilborn J W and McMahon C 1953 The determination of uranium and thorium in ores; Canadian Journal of Physics $\mathbf{3 1}$

Galbraith James H and Saunders Donald F 1983 Rock classification by characteristics of aerial gamma ray measurements; Journal of geochem. Expl. 18 pp. 4973

Grasty R L 1979 Gamma ray spectrometric methods in uranium exploration - Theory and operational procedures; Econ. Geology Rept. No.31 pp. 147-155
Krishnamurthy P 1988 Carbonatites of India; Exploration And Research For Atomic Minerals (EARFAM) 1 pp. 81115

Krishnamurthy P, Chaki A, Sinha R M and Singh S N 1988 Geology, geochemistry and genesis of metabasalts, metarhyolites and the associated uranium mineralization at Bodal, Rajanandgaon district, MP and implications for uranium exploration in central India; Exploration And Research For Atomic Minerals (EARFAM) 1 pp. 13-39

Tompkins Linde A 1987 Exploration for kimberlites in the South West Goia's Region, Brazil, mineral chemistry of stream sediment samples; Journal of Geochem. Expl. 27 pp. $1-28$

Rickwood P C 1989 Boundary lines within petrologic diagrams which use oxides of major and minor elements; Lithos 22 pp. 247-263 